\title{
Characterization of Precursor and Secreted Forms of Human Angiotensinogen
}

Duncan J. Campbell, Jacob Bouhnik, Erique Coezy, Joël Menard, and Pierre Corvol

Unité 36, Institut National de la Santé et de la Recherche Médicale (INSERM), 75005 Paris, France

\section{Abstract}

To define the basis of the heterogeneity of angiotensinogen, we have characterized (a) the immunoreactivity of high molecular weight (HMW) and low molecular weight (LMW) plasma angiotensinogen, $(b)$ the angiotensinogen precursor synthesized by cell-free translation, and (c) angiotensinogen secreted by human hepatoma (Hep G2) cells. Angiotensinogen precursor synthesized by rabbit reticulocyte lysate primed with RNA prepared from liver or Hep G2 cells was compared with angiotensinogen secreted by Hep G2 cells by using immunoprecipitation and sodium dodecyl sulfate-polyacrylamide gel electrophoresis (SDS-PAGE). So as to assess the contribution of $\mathrm{N}$-glycosylation of angiotensinogen, Hep G2 cells were incubated in the presence of tunicamycin. Glycosylation of secreted angiotensinogen was further characterized by using (a) chromatography on concanavalin A-Sepharose, (b) digestion with neuraminidase, and (c) treatment with trifluoromethane sulfonic acid. In Sephadex G-200 column chromatography, HMW plasma angiotensinogen eluted just after the column void volume and was clearly separated from LMW angiotensinogen which eluted just before bovine serum albumin. Both HMW and LMW plasma angiotensinogen were shown to bind to monoclonal and polyclonal antibodies raised against pure LMW angiotensinogen. Only one angiotensinogen precursor (mol wt 50,000) was identified by cell-free translation which, after cleavage by renin, was reduced to mol wt 45,600 . Angiotensinogen secreted by Hep G2 cells showed electrophoretic heterogeneity (mol wt 53,100-65,400). Tunicamycin-treated Hep $G 2$ cells secreted five discrete forms of angiotensinogen, a predominant form of mol wt 46,200 , with other forms (mol wt $46,800,48,100,49,200$, and 49,600 ) representing $10 \%$ of secreted angiotensinogen. All five forms showed a similar reduction in molecular weight after cleavage by renin. The predominant 46,200-mol wt protein represented nonglycosylated angiotensinogen in that, after cleavage by renin, it had an electrophoretic mobility (mol wt 45,600 ) identical to the desangiotensin I-angiotensinogen resulting from renin cleavage of the angiotensinogen precursor. The other higher molecular weight forms of angiotensinogen secreted by tunicamycintreated Hep G2 cells were shown to represent $O$-glycosylated angiotensinogen in that they were reduced to $46,200 \mathrm{~mol}$ wt

This work was reported in part at the Seventh International Congress of Endocrinology, 1-7 July 1984, Quebec City, Canada.

Dr. Campbell is presently with the Laboratory of Molecular Endocrinology, Massachusetts General Hospital, Boston, MA. Address reprint requests to Dr. Corvol, INSERM U 36, 17, rue du Fer-àMoulin, 75005 Paris, France.

Received for publication 26 September 1984 and in revised form 15 January 1985.

J. Clin. Invest.

(c) The American Society for Clinical Investigation, Inc. 0021-9738/85/06/1880/14 \$1.00

Volume 75 , June 1985, 1880-1893 by treatment with trifluoromethane sulfonic acid. Dexamethasone $\left(10^{-7}\right.$ and $\left.10^{-6} \mathrm{M}\right)$ stimulated angiotensinogen secretion by Hep G2 cells two- to fourfold, both in the absence and presence of tunicamycin. However, a small stimulatory effect of mestranol $\left(10^{-7} \mathrm{M}\right)$ was evident only in the presence of tunicamycin. Neither dexamethasone nor mestranol influenced the electrophoretic pattern (SDS-PAGE) of angiotensinogen secreted by Hep G2 cells. However, when incubation media were chromatographed on Sephadex G-200 with subsequent immunoprecipitation of the column fractions, both dexamethasone and mestranol were shown to stimulate the secretion of HMW angiotensinogen (eluting just after the column void volume) which, on SDS-PAGE, migrated in a position identical to LMW angiotensinogen. From these studies, we conclude that all forms of human angiotensinogen are derived from a single precursor. The heterogeneity of secreted angiotensinogen represents differences in posttranslational processing of angiotensinogen. This processing includes both $N$ - and $O$-glycosylation, and also the formation of HMW complexes (HMW angiotensinogen) through association either with other angiotensinogen molecules or with some other protein(s) whose secretion by hepatocytes is stimulated by glucocorticoids and estrogens.

\section{Introduction}

Angiotensin plays a major role in the control of blood pressure and in fluid and electrolyte homeostasis. The only known precursor of angiotensin is angiotensinogen (renin substrate), a glycoprotein secreted by the liver and also recently shown to be synthesized by the brain (1). Renin (EC 3.4.99.19) cleaves angiotensinogen at a single site between amino acids 10 and 11 to produce the decapeptide angiotensin $\mathrm{I}(\mathrm{AI})^{1}$ and des-AIangiotensinogen (2-5). AI is subsequently converted to the biologically active angiotensin II (AII) by angiotensin-converting enzyme (dipeptidyl carboxypeptidase, peptidyldipeptide hydrolase; EC 3.4.15.1), which cleaves the carboxyl dipeptide from AI (6).

Previous studies of plasma angiotensinogen in humans (721 ), hogs (22), rats $(4,23-25)$, and rabbits (26) have demonstrated that plasma angiotensinogen is heterogeneous with respect to its electrophoretic behavior and behavior on gel and ion-exchange chromatography, and isoelectric focusing. Whereas plasma angiotensinogen has been purified to homogeneity, as demonstrated by $\mathrm{N}$-terminal amino acid determination $(4,5,22)$, each purified fraction has represented only a proportion of the different molecular species present in plasma.

1. Abbreviations used in this paper: AI, angiotensin I; AII, angiotensin II; des-AI-angiotensinogen, des-angiotensin I-angiotensinogen; FCS; fetal calf serum; Hep G2, human hepatoma; HMW, high molecular weight; LMW, low molecular weight; PAGE, polyacrylamide gel electrophoresis; PSB, Pansorbin; RIA, radioimmunoassay; RPMI, Roswell Park Memorial Institute (medium); TCA, trichloroacetic acid; TFMS, trifluoromethane sulfonic acid. 
Several studies have suggested that variable glycosylation may be the basis for the heterogeneity of plasma angiotensinogen, and our previous studies (27) have demonstrated that the heterogeneity of rat plasma angiotensinogen can be fully accounted for by variation in $\mathrm{N}$-glycosylation. However, in man, in addition to the predominant form of angiotensinogen (low molecular weight, LMW) with mol wt $\sim 60,000$, a high molecular weight (HMW) form of plasma angiotensinogen has been identified $(7,8,11,12,17,18)$. This HMW angiotensinogen has a reduced mobility, compared with LMW angiotensinogen, on nondenaturing polyacrylamide gel electrophoresis (PAGE), and elutes close to the void volume on Sephadex G200 column chromatography $(7,8)$. HMW angiotensinogen is of increased abundance in plasma of pregnant women, women taking oral contraceptives, and patients on glucocorticoid therapy or with advanced essential hypertension or hypertension with uremia (12). In these studies, angiotensinogen was measured by the amount of AI generated by incubation with renin. Eggena et al. $(11,12)$ have reported that a polyclonal antibody raised against $\mathrm{LMW}$ angiotensinogen does not recognize HMW angiotensinogen, raising the question whether $\mathrm{HMW}$ and LMW angiotensinogen differ in amino acid sequence.

Kageyama et al. (28) have recently cloned and sequenced a cDNA prepared from liver RNA which has provided the primary structure of LMW human angiotensinogen. However, the relationship of the initial translation product to the various forms of secreted angiotensinogen remains to be defined, in particular, whether all forms of angiotensinogen are derived from a single precursor.

In the present study we have examined the bases of the heterogeneity of human plasma angiotensinogen by using several experimental approaches. Our studies were performed using two polyclonal and two monoclonal antibodies raised against pure human LMW angiotensinogen. Initially, we showed that all of these antibodies recognized both HMW and LMW plasma angiotensinogen. We subsequently used these antibodies to characterize the precursor of angiotensinogen synthesized by cell-free translation of RNA prepared from human liver and human hepatoma (Hep G2) cells (29), by using immunoprecipitation and sodium dodecyl sulfate-polyacrylamide gel electrophoresis (SDS-PAGE). We have compared the angiotensinogen precursor with plasma angiotensinogen and with angiotensinogen secreted by Hep G2 cells. We have characterized the nature of glycosylation of secreted angiotensinogen using (a) tunicamycin to inhibit $\mathrm{N}$-glycosylation, (b) concanavalin A-Sepharose column chromatography, $(c)$ neuraminidase to remove sialic acid residues, and $(d)$ trifluoromethane sulfonic acid to deglycosylate angiotensinogen. Finally, we have studied the effects of dexamethasone and mestranol on these secreted forms of angiotensinogen.

\section{Methods}

Pure human angiotensinogen was a gift from Dr. D. A. Tewksbury (Marshfield Medical Foundation, Inc., Marshfield, WI). It had an AI content of $21 \mu \mathrm{g} / \mathrm{mg}$ protein, which is close to the expected theoretical value of one molecule of angiotensin per molecule of angiotensinogen (mol wt 61,400) (19).

Plasma was obtained by centrifugation of blood anticoagulated with EDTA, and stored at $-30^{\circ} \mathrm{C}$.

Antibodies to human angiotensinogen. The preparation and characterization of polyclonal antibodies raised against pure angiotensinogen have been described previously (21). Polyclonal antibodies $\mathrm{HCl}$ and MAP each had a dissociation constant of $\sim 0.5 \times 10^{-11} \mathrm{M}$. The prep- aration of monoclonal antibodies will be described elsewhere (Bouhnik, J., manuscript in preparation). Monoclonal antibodies $\mathrm{F}_{60} 7 \mathrm{Cl1}$ and $\mathrm{F}_{60} 1 \mathrm{C} 11$ had dissociation constants of $0.86 \times 10^{-12} \mathrm{M}$ and 0.85 $\times 10^{-11} \mathrm{M}$, respectively. Antibody $\mathrm{F}_{60} 1 \mathrm{C} 11$, but not $\mathrm{F}_{60} 7 \mathrm{C} 11$, recognized angiotensinogen of marmoset (Callithrix jacchus) and baboon (Papio papio). Neither monoclonal antibody recognized angiotensinogen of dog, rat, hog, rabbit or fetal calf, or AI, AII, or horse tetradecapeptide.

Measurement of angiotensinogen. Angiotensinogen was measured either by direct radioimmunoassay (RIA) or by RIA of AI generated by incubation with renin sufficient to completely exhaust the angiotensinogen (enzymatic assay), as described elsewhere (21). The sensitivity of the direct angiotensinogen RIA (polyclonal antibodies) and the AI RIA, i.e., the amount of antigen necessary to obtain a $10 \%$ decrease in bound tracer, was $2.5 \mathrm{fmol}$ for each assay. However, because the enzymatic assay of angiotensinogen involved a dilution of at least fivefold during the incubation with renin, the sensitivity of the enzymatic assay of angiotensinogen was approximately one-fifth of that of the direct RIA.

Sephadex G-200 column chromatography. Plasma $(100 \mu \mathrm{l})$ or incubation media of Hep G2 cells $(0.8 \mathrm{ml})$ were chromatographed at $4^{\circ} \mathrm{C}$ on columns $(1.5 \times 28 \mathrm{~cm})$ of Sephadex G-200 Superfine (Pharmacia Fine Chemicals, Uppsala, Sweden) equilibrated and eluted with 0.05 $M$ Tris $\mathrm{HCl}, 0.1 \mathrm{M} \mathrm{NaCl}, 3 \mathrm{mM}$ EDTA, $15.4 \mathrm{mM}$ sodium azide, 1 $\mathrm{mg} / \mathrm{ml}$ bovine serum albumin, pH $8.0\left(20^{\circ} \mathrm{C}\right)$. Fractions of $1.0 \mathrm{ml}$ were collected at a flow rate of 3-6 ml/h. Fractions were either immunoprecipitated or assayed immediately, or stored at $-30^{\circ} \mathrm{C}$ prior to assay. Recovery of angiotensinogen was $69 \%$ (range $47-96 \%$ ) for incubation media and $117 \%$ (range 105-130\%) for plasma. Molecular weight standards were obtained from Pharmacia.

Cell-free translation. RNA was prepared from human liver or Hep G2 cells by a modification (1) of the method of Chirgwin et al. (30). For some experiments, mRNA was purified by chromatography on oligo(dT)-cellulose (31), then fractionated by electrophoresis on a $1 \%$ low-melt agarose gel containing $12.5 \mathrm{mM}$ methylmercury hydroxide (32). RNA was translated using a nuclease-treated rabbit reticulocyte lysate (27).

Cell culture experiments. Hep G2 cells were cultured to confluency in Roswell Park Memorial Institute medium (RPMI) (Bio-Cult, Gibco Laboratories, Grand Island, NY) containing 5\% fetal calf serum (FCS), $0.6 \mu \mathrm{g} / \mathrm{ml}$ insulin (bovine, Sigma Chemical Co., St. Louis, MO), 200 $\mathrm{mM}$ glutamine, and $50 \mu \mathrm{g} / \mathrm{ml}$ gentamycin. $12 \mathrm{~h}$ before the addition of radiolabeled precursors, the medium was changed to RPMI with Hanks' salts, $200 \mathrm{mM}$ glutamine, and 5\% FCS. $1 \mathrm{~h}$ before the addition of radiolabeled precursors, the medium was changed to RPMI with Hanks' salts and $200 \mathrm{mM}$ glutamine, but without serum, glucose, or methionine. The same medium was used both to rinse the cells completely free of FCS and for the radiolabeling experiment $(1 \mathrm{ml} / 4$ $\mathrm{cm}^{2}$ well containing $\sim 1 \times 10^{6}$ cells). To control flasks, both glucose and methionine were added (final concentrations were $10 \mathrm{mM}$ and $0.13 \mu \mathrm{M}$, respectively). Similarly, glucose was added to wells containing ${ }^{35}$ S]methionine (New England Nuclear, Boston, MA; 1,060 Ci/mmol; $120 \mu \mathrm{Ci}$ /well), and methionine was added to wells containing $\left[{ }^{3} \mathrm{H}\right]$ glucosamine (D-[6- $\left.{ }^{3} \mathrm{H}\right]$ glucosamine hydrochloride; Amersham, Buckinghamshire, England; $27 \mathrm{Ci} / \mathrm{mmol} ; 120 \mu \mathrm{Ci} /$ well). After $8 \mathrm{~h}$, the medium was aspirated and stored at $-30^{\circ} \mathrm{C}$.

To inhibit $N$-glycosylation, tunicamycin (Sigma Chemical Co.; 1 , 5 , or $10 \mu \mathrm{g} / \mathrm{ml}$ ) was added to cultures from $12 \mathrm{~h}$ before the addition of radiolabel until the end of the experiment.

For study of the effect of dexamethasone (Sigma Chemical Co.) and mestranol (Prophac, Gentilly, France), Hep G2 cells were cultured as described above except that the medium contained $10 \%$ FCS which had been depleted of endogenous steroids by treatment with dextrancoated charcoal (33). This higher concentration of FCS was necessary for optimal growth to confluency. Cells were incubated in this medium, in the absence or presence of steroid, for $4 \mathrm{~d}$ prior to the radiolabeling experiment.

Secretion of radiolabeled products by Hep G2 cells was assessed by trichloroacetic acid (TCA)-precipitable radioactivity (27). 
Immunoprecipitation and electrophoresis. Angiotensinogen synthesized by cell-free translation or secreted by Hep G2 cells was immunoprecipitated with polyclonal antibodies using a $10 \%$ suspension of Staphylococcus aureus (Pansorbin, PSB, Calbiochem, La Jolla, CA), as described previously (27) except that $10 \mu$ l of PSB were coated with $0.1-0.2 \mu \mathrm{l}$ of antibody. Immunoprecipitation by polyclonal antibodies was shown to be quantitative as determined by co-immunoprecipitation of ${ }^{125}$ I-iodoangiotensinogen. For immunoprecipitation with monoclonal antibodies, $10 \mu \mathrm{l}$ of PSB were first coated with $1 \mu \mathrm{l}$ of rabbit antimouse immunoglobulin (Nordic Immunological Laboratories, Tilburg, The Netherlands), then, after washing, with $1 \mu \mathrm{l}$ of monoclonal antibody (hybridoma culture supernatant). Subsequently, immunoprecipitation was performed as previously described for polyclonal antibodies (27).

The methods used for SDS-PAGE on 9\% gels and autoradiography have been described previously (27). Molecular weight standards were obtained from Bio-Rad Laboratories (Richmond, CA). For some experiments, reticulocyte lysate or incubation media were incubated with pure human renin (34) before immunoprecipitation.

For quantitation of immunoprecipitable radiolabeled products secreted by Hep G2 cells, the PSB antibody-antigen complex was solubilized with $0.5 \mathrm{ml}$ of Protosol (New England Nuclear) at $60^{\circ} \mathrm{C}$ for $30 \mathrm{~min}$. After neutralization with $50 \mu \mathrm{l}$ of glacial acetic acid, 10 $\mathrm{ml}$ of toluene scintillator (Packard Instrument Co., Inc., Downers Grove, IL) was added, and the radioactivity was determined. Immunoprecipitable radioactivity was corrected for nonspecific radioactivity determined from parallel experiments using PSB coated with nonimmune rabbit serum.

Chromatography on concanavalin A-Sepharose. Incubation media were applied to small columns of concanavalin A-Sepharose (Pharmacia Fine Chemicals) equilibrated at room temperature with binding buffer ( $0.05 \mathrm{M}$ Tris $\mathrm{HCl}, 0.15 \mathrm{M} \mathrm{NaCl}, 1 \mathrm{mM} \mathrm{CaCl}, 15.4 \mathrm{mM}$ sodium azide, $\mathrm{pH} 7.0,20^{\circ} \mathrm{C}$ ). After washing with binding buffer, material bound to the concanavalin A was eluted with $0.4 \mathrm{M} \alpha$-methyl-D-mannopyranoside, $15.4 \mathrm{mM}$ sodium azide. The pooled flow-through and washes, representing unbound material, and the pooled eluate, representing the bound fraction, were then immunoprecipitated and subjected to SDS-PAGE and autoradiography.

Treatment with neuraminidase. Incubation medium was immunoprecipitated and the PSB antibody-antigen complex washed four times with $200 \mu \mathrm{l}$ of immunoprecipitation buffer (27) and once with $200 \mu \mathrm{l}$ of water. The PSB antibody-antigen complex was then suspended in $50 \mu \mathrm{l}$ of $0.05 \mathrm{M}$ sodium acetate, $0.5 \mathrm{mM} \mathrm{CaCl}, \mathrm{pH} 5.6\left(20^{\circ} \mathrm{C}\right)$ containing $0.025 \mathrm{U}$ of neuraminidase (Clostridium perfringens; Boehringer Mannheim-France SA, Meylan, France). Control samples were suspended in $50 \mu \mathrm{l}$ of water. After incubation at $37^{\circ} \mathrm{C}$ for $6 \mathrm{~h}, 5 \mu \mathrm{l} 2-$ mercaptoethanol, $20 \mu \mathrm{l}$ of $10 \%$ SDS, and $20 \mu \mathrm{l}$ of $0.004 \%$ bromophenol blue in $50 \%$ glycerol in stacking gel buffer (35) were added. The mixture was placed in a boiling water bath for $5 \mathrm{~min}$, then centrifuged and the supernatant run on SDS-PAGE.

Deglycosylation with trifluoromethane sulfonic acid (TFMS). Bovine serum albumin $(0.5 \mathrm{mg})$ was added as carrier protein to $200 \mu \mathrm{l}$ of incubation medium and deglycosylation with TFMS performed as described by Kalyan and Bahl $(36,37)$, except that in some experiments the reaction was terminated with piperidine instead of pyridine. After dialysis against water, angiotensinogen was immunoprecipitated and subjected to SDS-PAGE (27).

Statistical methods. Results are expressed as mean \pm 1 SE. Statistical comparison was either by Student's $t$ test (38) or Mann-Whitney U test (39).

\section{Results}

Recognition of HMW and LMW angiotensinogen by both polyclonal and both monoclonal antibodies. As previously described by Gordon and Sachin (8), chromatography of plasma on Sephadex G-200 Superfine clearly separated HMW from LMW angiotensinogen: HMW angiotensinogen eluted just after the column void volume and LMW angiotensinogen eluted just before bovine serum albumin. The results obtained for plasma from a woman in the third trimester of pregnancy are shown in Fig. 1. Column fractions were assayed for angiotensinogen by using both the enzymatic assay and the direct RIA. Whereas there was a good agreement between the enzymatic assay and the direct RIA for LMW angiotensinogen, for HMW angiotensinogen the ratio of values obtained by the direct RIA and the enzymatic assay was 0.26 . Moreover, in a series of eight different plasmas from two males, two females with normal menstrual cycles, two females taking oral contraceptives, and two women in the third trimester of pregnancy, the ratio of values obtained by the direct assay and the enzymatic assay was similar $(0.25 \pm 0.01$, mean $\pm \mathrm{SE}, n=8)$, despite a fivefold variation in concentration of plasma angiotensinogen with varying proportions $(2.3-16.2 \%$ by enzymatic assay) of HMW angiotensinogen. For LMW angiotensinogen, the ratio of values obtained by the direct RIA and the enzymatic assay was $1.03 \pm 0.04$ (mean $\pm \mathrm{SE}, n=8)$. The displacement of ${ }^{125} \mathrm{I}$-iodoangiotensinogen by HMW angiotensinogen in the direct RIA was parallel to that for LMW angiotensinogen and for pure angiotensinogen (data not shown).

To determine whether the discrepancy between the direct RIA and the enzymatic assay of HMW angiotensinogen represented a reduced affinity of HMW angiotensinogen for the antibody, or the presence of a second, nonimmunoreactive,

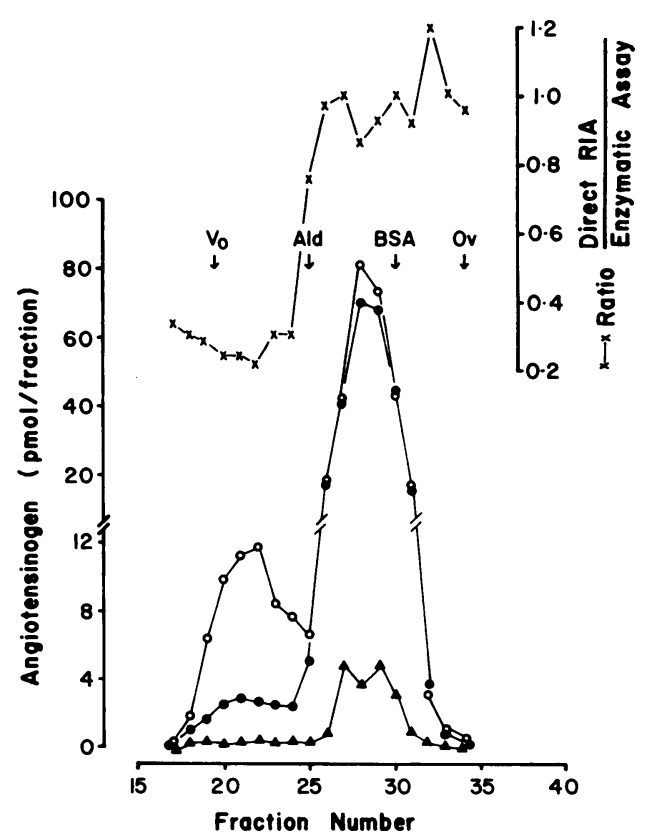

Figure 1. Comparison of direct RIA and enzymatic assay of HMW and LMW plasma angiotensinogen. Plasma (100 $\mu \mathrm{l})$ from a woman in the third trimester of pregnancy was chromatographed on Sephadex G-200 Superfine and the column fractions $(1.0 \mathrm{ml})$ were assayed for angiotensinogen by using either the direct RIA $(\bullet)$ or the enzymatic assay. The enzymatic assay was performed both before (O) and after absorption of aliquots of each column fraction with antibody ( $\triangle$ ) immobilized onto Pansorbin. HMW angiotensinogen eluted just after the column void volume $\left(V_{0}\right)$; LMW angiotensinogen eluted just before bovine serum albumin (BSA, mol wt 67,000). Ald, aldolase, mol wt 158,000; Ov, ovalbumin, mol wt 43,000. 
species of angiotensinogen, column fractions were absorbed with immobilized antibody before enzymatic assay. Aliquots containing $<0.2 \mathrm{pmol}$ (mean $0.1 \mathrm{pmol}$ ) angiotensinogen were taken from each column fraction and incubated overnight at $4^{\circ} \mathrm{C}$ with $25 \mu$ l of PSB (10\%) coated with $2.5 \mu$ l of antibody $\mathrm{HCl}$ in a total volume of $150 \mu \mathrm{l}$. Subsequently, after centrifugation, $100 \mu \mathrm{l}$ of the supernatant was taken for enzymatic assay. This absorption of column fractions with immobilized antibody removed an average of $93 \%$ of both HMW and LMW angiotensinogen (Fig. 1). In the same experiment, 93\% of 0.078 pmol pure angiotensinogen was removed by immobilized antibody, whereas only $7 \%$ was removed by PSB coated with nonimmune serum. These data demonstrated that antibody $\mathrm{HCl}$ was able to immunoprecipitate quantitatively both HMW and LMW angiotensinogen, and therefore, suggested that the difference in values obtained by the direct RIA and the enzymatic assay of HMW angiotensinogen represented a reduced affinity of $\mathrm{HMW}$ angiotensinogen for the antibody.

Both polyclonal and both monoclonal antibodies recognized HMW angiotensinogen (Fig. 2). The results obtained by direct RIA that used antibody MAP were similar to those obtained with antibody $\mathrm{HCl}$. However, the values obtained using the monoclonal antibodies were approximately half the values obtained with the polyclonal antibodies. For LMW angioten-

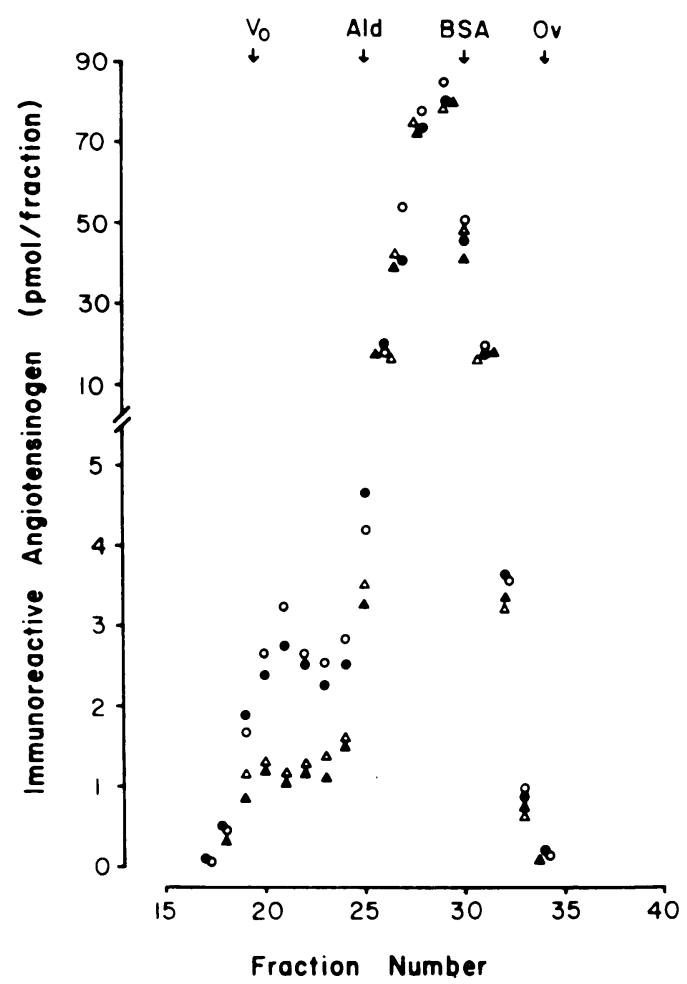

Figure 2. Recognition of both HMW and LMW plasma angiotensinogen by both polyclonal and monoclonal antibodies. Plasma (100 $\mu \mathrm{l})$ from a woman in the third trimester of pregnancy was chromatographed on Sephadex G-200 Superfine and the column fractions (1.0 $\mathrm{ml}$ ) were assayed for angiotensinogen using the indicated antibodies in a direct radioimmunoassay. Shown in the figure is the immunoreactive angiotensinogen measured using each antibody. (๑), $\mathrm{HCl} ;(\mathrm{O})$, MAP; ( $\Delta), \mathrm{F}_{60} 7 \mathrm{C} 11 ;(\Delta), \mathrm{F}_{60} 1 \mathrm{C} 11$. HMW angiotensinogen eluted just after the column void volume $\left(V_{0}\right)$; LMW angiotensinogen eluted just before bovine serum albumin (BSA, mol wt 67,000). Ald, aldolase, mol wt 158,000; Ov, ovalbumin, mol wt 43,000. sinogen, all four antibodies gave equivalent results when used in the direct RIA (Fig. 2).

Identification of the angiotensinogen precursor. Immunoprecipitation and SDS-PAGE of reticulocyte lysate primed with liver RNA revealed only a single angiotensinogen precursor of mol wt 50,000. After cleavage by renin, the precursor was reduced to mol wt 45,600 (Fig. 3), representing des-AIangiotensinogen. Both the precursor and des-AI-angiotensinogen were immunoprecipitated by both polyclonal antibodies. However, neither monoclonal antibody immunoprecipitated either form of angiotensinogen (Fig. 3). Identical results were obtained with RNA prepared from livers of three individuals (all male) and also RNA prepared from Hep G2 cells (data not shown).

Migrating ahead of the angiotensinogen precursor on SDSPAGE was a protein ( $\mathrm{mol} \mathrm{wt} 48,000$ ), which in many experiments (see Fig. 8) showed a decreased abundance after incubation with renin. However, this band was considered to be nonspecific since it was also seen, though often in lesser abundance, following immunoprecipitation with nonimmune serum (Fig. 3). Moreover, this band persisted after preabsorption of antibody $\mathrm{HCl}$ with pure angiotensinogen, whereas both the 50,000 -mol wt precursor and the 45,600-mol wt renin cleavage product were extinguished by this procedure (data not shown). Other negative controls included the failure to immunoprecipitate the 50,000 -mol wt precursor from lysate incubated without

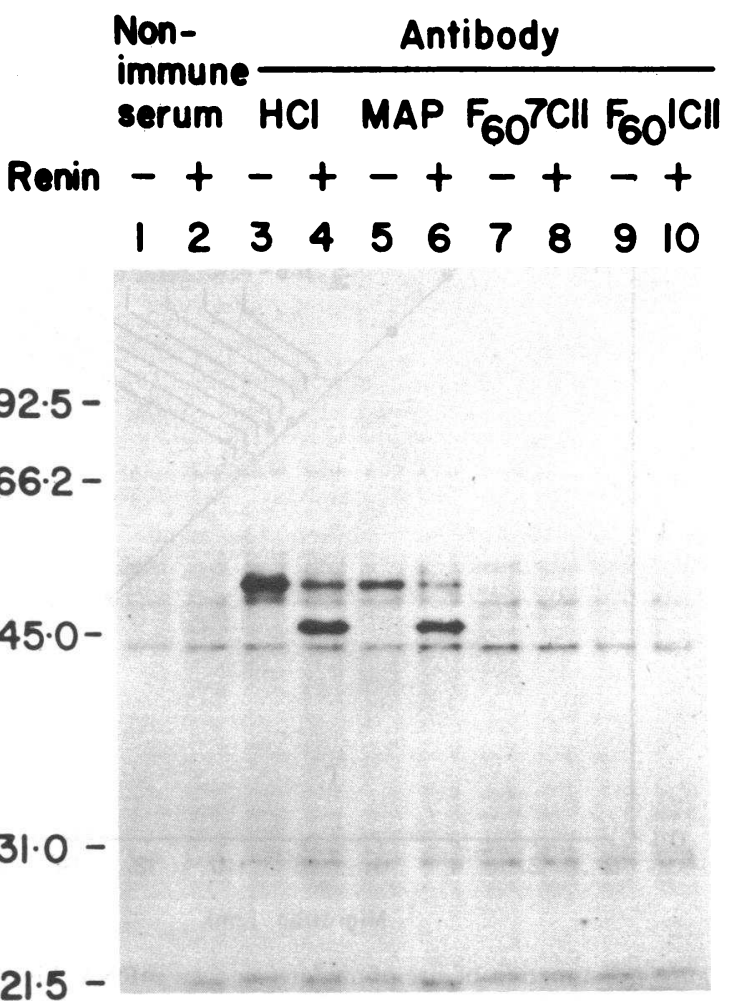

Figure 3. Identification of angiotensinogen precursor synthesized by cell-free translation. Liver RNA was translated using reticulocyte lysate and then incubated for $60 \mathrm{~min}$ at $37^{\circ} \mathrm{C}$ with cycloheximide $(10$ $\mu \mathrm{g} / \mathrm{ml})$ in the absence or presence of renin $(0.5 \mathrm{Goldblatt} \mathrm{U} / \mathrm{ml})$. The cycloheximide was added to prevent further translation (27). The lysate was then immunoprecipitated and subjected to SDS-PAGE and autoradiography. Shown in the figure is an autoradiogram of the SDS-PAGE. 
RNA or from lysate primed with RNA prepared from human renal cortex or rat liver (data not shown).

Fractionation of liver mRNA on an agarose gel showed angiotensinogen mRNA to be $\sim 2,000$ bases in length (Fig. 4), and confirmed our finding of only one precursor.

Angiotensinogen synthesis and secretion by Hep G2 cells. Hep G2 cells secreted angiotensinogen at a rate of 1-4 pmol per $10^{6}$ cells per $8 \mathrm{~h}$. After culture for $4 \mathrm{~d}$ in steroid-free medium, the secretion rate was $\sim 0.5$ pmol per $10^{6}$ cells per 8 h. Tunicamycin $(1-10 \mu \mathrm{g} / \mathrm{ml})$ caused a $40-60 \%$ reduction in angiotensinogen secretion rate, with a corresponding reduction in protein synthesis and secretion, as shown by TCA-precipitable $\left[{ }^{35}\right.$ S $]$ methionine (Table I).

Angiotensinogen secreted by Hep G2 cells, either in the absence or presence of tunicamycin, when quantitated by the direct RIA caused a displacement of ${ }^{125}$ I-iodoangiotensinogen which was parallel to that of pure angiotensinogen (Fig. 5). There was a good correspondence between the direct RIA and the enzymatic assay (Fig. 6).

On SDS-PAGE, $\left[{ }^{35} \mathrm{~S}\right]$ methionine labeled angiotensinogen secreted by Hep G2 cells migrated as a diffuse band of mol wt 53,100-65,400 (Fig. 7). For tunicamycin-treated Hep G2 cells, five discrete bands were observed on SDS-PAGE: a predominant

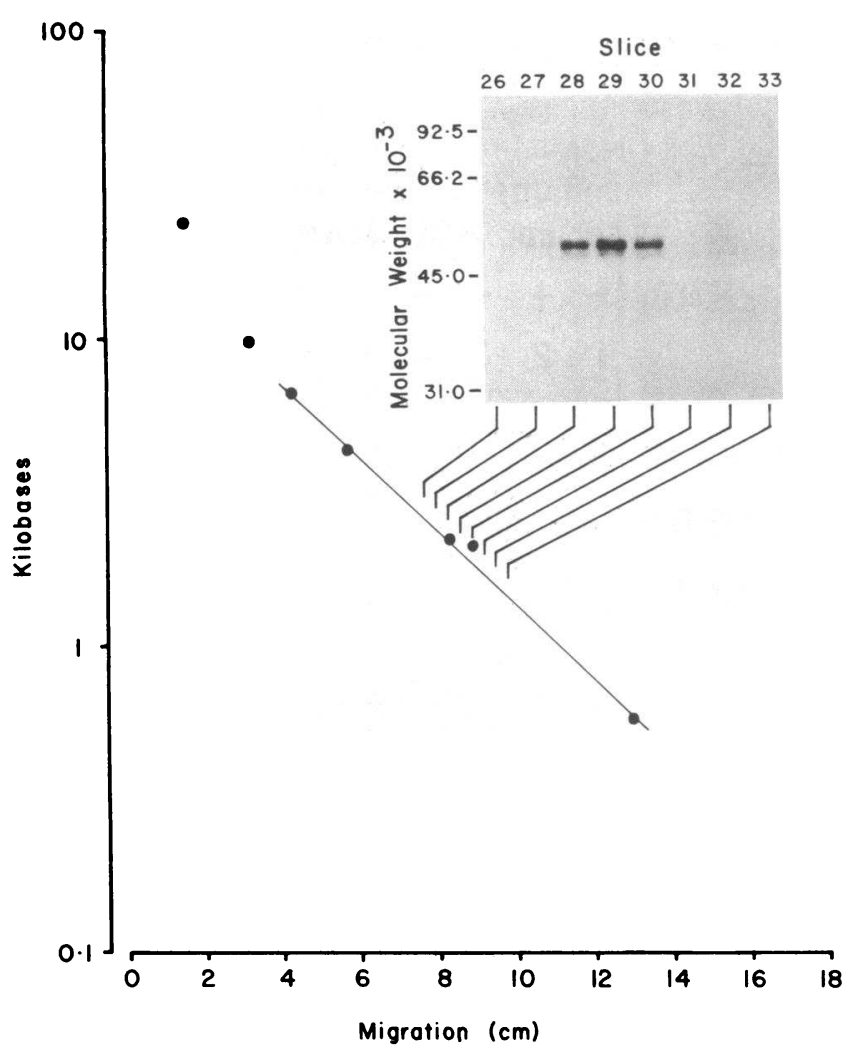

Figure 4. Estimation of size of angiotensinogen mRNA. Liver mRNA was fractionated on a $1 \%$ low-melt agarose gel in the presence of $12.5 \mathrm{mM}$ methylmercury hydroxide. The gel was divided into 3-mm slices and mRNA was extracted and translated using reticulocyte lysate. The lysate was then immunoprecipitated (antibody $\mathrm{HCl}$ ) and subjected to SDS-PAGE and autoradiography. Shown in the figure is an autoradiogram of SDS-PAGE for slices 26-33, and their correspondence to the molecular weight standards on the agarose gel (fragment mixture from cleavage of lambda phage DNA with restriction endonuclease Hind III, and visualized with ethidium bromide).
Table I. Effect of Tunicamycin on TCA-precipitable and Immunoprecipitable $\left[{ }^{35}\right.$ S $]$ Methionine and $\left[{ }^{3} \mathrm{H}\right]$ Glucosamine, and Angiotensinogen Production by Hep G2 Cells

\begin{tabular}{llll}
\hline $\begin{array}{l}\text { Tunicamycin concentration } \\
(\mu \mathrm{g} / \mathrm{ml})\end{array}$ & 1 & 5 & 10 \\
\hline $\begin{array}{c}{ }^{35} \text { S]Methionine } \\
\text { (percent of control) }\end{array}$ & $\%$ & $\%$ & $\%$ \\
$\begin{array}{c}\text { TCA precipitable } \\
\text { Immunoprecipitable }\end{array}$ & $57 \pm 4$ & $50 \pm 2$ & $44 \pm 1$ \\
$\begin{array}{c}\left.\text { [ }{ }^{3} \mathrm{H}\right] \text { Glucosamine } \\
\text { (percent of control) }\end{array}$ & $12 \pm 9$ & $35 \pm 10$ & $17 \pm 4$ \\
$\begin{array}{c}\text { TCA precipitable } \\
\text { Immunoprecipitable }\end{array}$ & $4.6 \pm 1.2$ & $0.6 \pm 1.5$ & $0.5 \pm 0.8$ \\
$\begin{array}{c}\text { Angiotensinogen } \\
\text { (percent of control) }\end{array}$ & $45 \pm 10$ & $64 \pm 12$ & $56 \pm 4$ \\
\hline
\end{tabular}

Results expressed as percent (mean $\pm \mathrm{SE}$ ) of control incubations for two experiments (tunicamycin $1 \mu \mathrm{g} / \mathrm{ml}$ ) or one experiment (tunicamycin 5 and $10 \mu \mathrm{g} / \mathrm{ml}$ ), each experiment with duplicate incubations of $8 \mathrm{~h}$. For control incubations, TCA-precipitable and immunoprecipitable $\left[{ }^{35}\right.$ S $]$ methionine were $7.97 \pm 0.39(\mathrm{SE}) \times 10^{6}$ and $0.429 \pm 0.025 \times 10^{6} \mathrm{cpm}$, respectively; TCA-precipitable and immunoprecipitable $\left[{ }^{3} \mathrm{H}\right]$ glucosamine were $0.290 \pm 0.034 \times 10^{6}$ and $0.034 \pm 0.005 \times 10^{6} \mathrm{cpm}$, respectively; angiotensinogen production was $2.61 \pm 0.64$ pmol.

form of 46,200 mol wt and four minor forms (mol wt 46,800, $48,100,49,200$, and 49,600). By densitometric scanning of autoradiograms exposed for varying lengths of time and calculation of the relationship between peak area and duration of exposure for each band, these minor forms were estimated to comprise $10 \%$ of the total $\left[{ }^{35} S\right]$ methionine-labeled angiotensinogen secreted by tunicamycin treated Hep G2 cells. Of

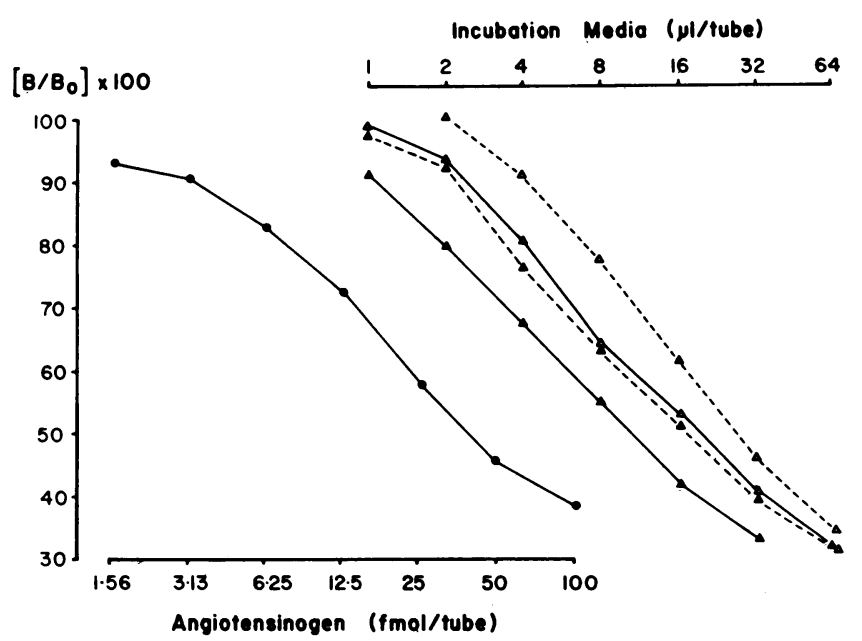

Figure 5. Displacement of ${ }^{125}$ I-iodoangiotensinogen from antibody $\mathrm{HCl}$ by pure plasma angiotensinogen and by angiotensinogen secreted by Hep G2 cells incubated in the absence $(\Delta)$ or the presence of tunicaymcin $(\Delta) . B / B_{0}$ is the ratio of bound ${ }^{125}$ I-iodoangiotensinogen to ${ }^{125}$ I-iodoangiotensinogen bound in the absence of angiotensinogen or incubation media. For incubation media, the solid and dashed lines represent data for different incubations. 


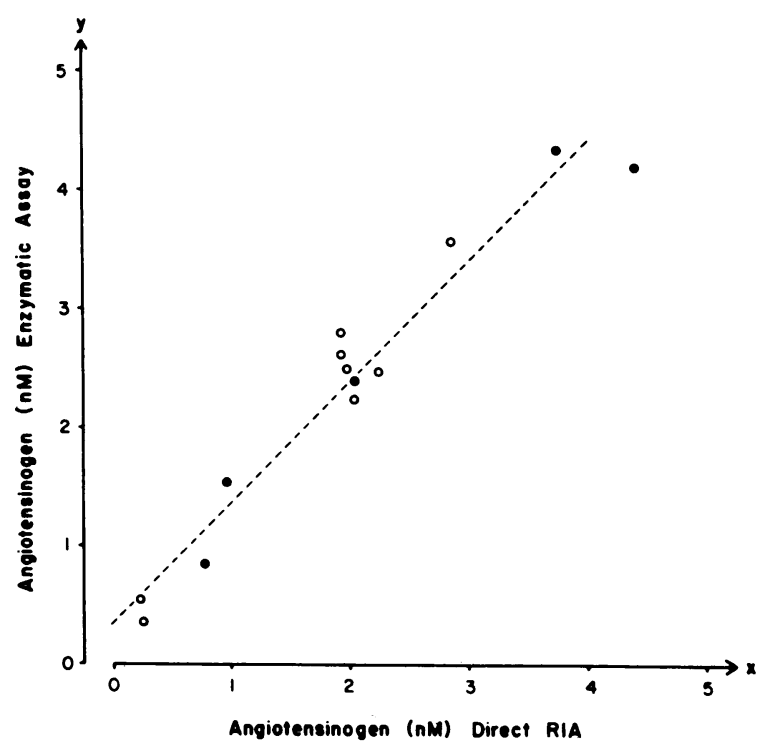

Figure 6. Comparison of direct RIA with enzymatic assay of angiotensinogen secreted by Hep G2 cells incubated in the absence $(\bullet)$ or presence of tunicamycin $(0)(1,5$, and $10 \mu \mathrm{g} / \mathrm{ml}) . y=0.39+0.99 x$; $r=0.97 ; n=13$.

these minor forms, those of mol wt 48,100 and 49,200 were the most abundant, whereas those of mol wt 46,800 and 49,600 were variable in occurrence.

All forms of angiotensinogen secreted by Hep G2 cells were recognized by both polyclonal and both monoclonal antibodies (Fig. 7). Preabsorption of antibody with pure angiotensinogen extinguished all forms (data not shown).

All five forms of angiotensinogen secreted by tunicamycintreated Hep G2 cells were cleaved by renin with an equal

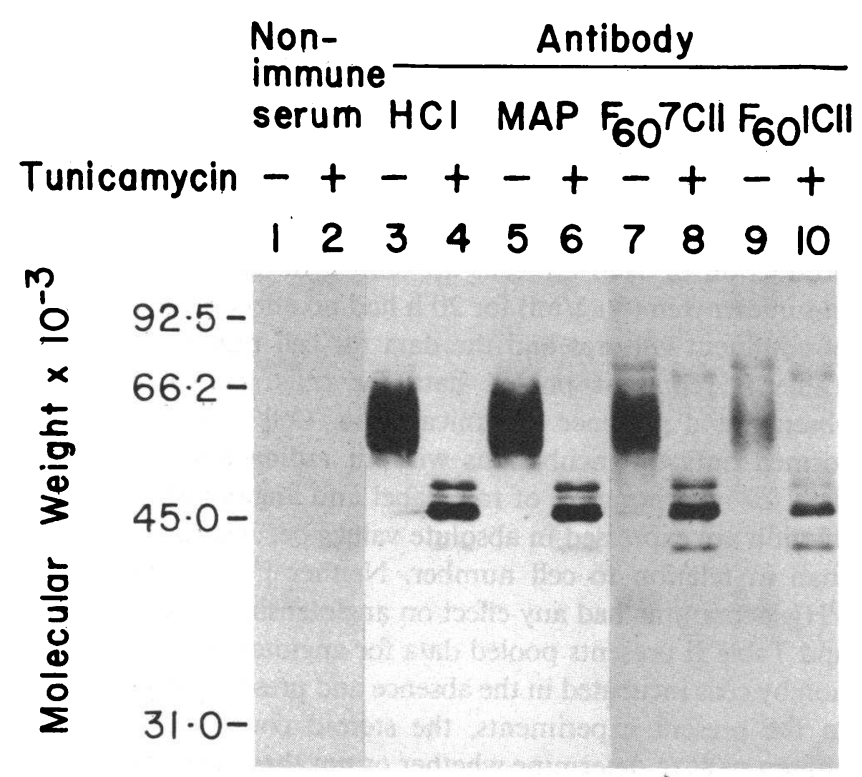

Figure 7. Secretion of angiotensinogen by Hep G2 cells. $\left[{ }^{35}\right.$ S]Methionine-labeled angiotensinogen secreted by Hep G2 cells incubated in the absence or presence of tunicamycin $(1 \mu \mathrm{g} / \mathrm{ml})$ was immunoprecipitated and subjected to SDS-PAGE and autoradiography. Shown in the figure is an autoradiogram of the SDS-PAGE. reduction in molecular weight (Fig. 8). The predominant 46,200-mol wt form, after cleavage by renin, had an identical mol wt $(45,600)$ to the des-AI-angiotensinogen resulting from renin cleavage of the precursor synthesized by cell-free translation (Fig. 8). The reticulocyte lysate does not glycosylate proteins. Thus the 46,200-mol wt angiotensinogen secreted by tunicamycin-treated cells represented nonglycosylated angiotensinogen, whereas the other higher molecular weight forms represented angiotensinogen with some posttranslational modification. That all five forms showed an equal change in molecular weight after cleavage by renin indicated that this posttranslational modification was an increase in molecular weight of the C-terminal portion of the angiotensinogen molecule; there was no evidence that any of the five forms contained an $\mathrm{N}$-terminal extension. The reduction in mol wt of 600 after cleavage by renin was only half the expected change, given the mol wt of AI of 1,297. This probably represents the failure of angiotensinogen and des-AI-angiotensinogen to migrate on SDS-PAGE in a manner identical to the molecular weight standards.

These higher molecular weight forms of angiotensinogen secreted by tunicamycin treated Hep G2 cells did not represent residual $\mathrm{N}$-glycosylation, since tunicamycin concentrations of 1,5 , and $10 \mu \mathrm{g} / \mathrm{ml}$ resulted in identical patterns on SDSPAGE (Fig. 9). Although $1 \mu \mathrm{g} / \mathrm{ml}$ of tunicamycin failed to completely inhibit the incorporation of $\left[{ }^{3} \mathrm{H}\right]$ glucosamine into angiotensinogen, both 5 and $10 \mu \mathrm{g} / \mathrm{ml}$ of tunicamycin completely inhibited $N$-glycosylation, as shown by immunoprecipitable $\left[{ }^{3} \mathrm{H}\right]$ glucosamine labeled angiotensinogen (Table I). The pattern on SDS-PAGE of $\left[{ }^{35} \mathrm{~S}\right]$ methionine-labeled angiotensinogen was identical for samples prepared in 0,5 , and $10 \% 2$ mercaptoethanol (data not shown).

\section{Incubation Media Lysate $\begin{array}{llllllllll}1 & 2 & 3 & 4 & 5 & 6 & 7 & 8 & 9 & 10\end{array}$}

Renin $\left(G U / m 1 \times 10^{-2}\right) 0612255006122550$

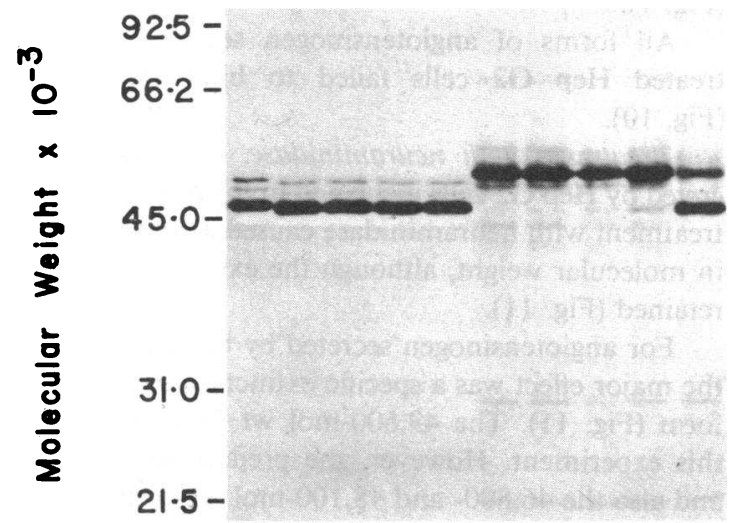

Figure 8. Cleavage by renin of precursor and secreted forms of angiotensinogen. $\left[{ }^{35} \mathrm{~S}\right]$ Methionine-labeled angiotensinogen precursor synthesized by cell-free translation, and angiotensinogen secreted by Hep G2 cells incubated in the presence of tunicamycin $(10 \mu \mathrm{g} / \mathrm{ml})$, were incubated with renin, then immunoprecipitated (antibody $\mathrm{HCl}$ ) and subjected to SDS-PAGE and autoradiography. Shown in the figure is an autoradiograph of SDS-PAGE. Incubation media and reticulocyte lysate $(20 \mu \mathrm{l})$ were incubated with the indicated concentration of renin (GU, Goldblatt units) for $60 \mathrm{~min}$ at $37^{\circ} \mathrm{C}$. The lysate also contained cycloheximide $(10 \mu \mathrm{g} / \mathrm{ml})$ to prevent translation during the incubation with renin (27). 


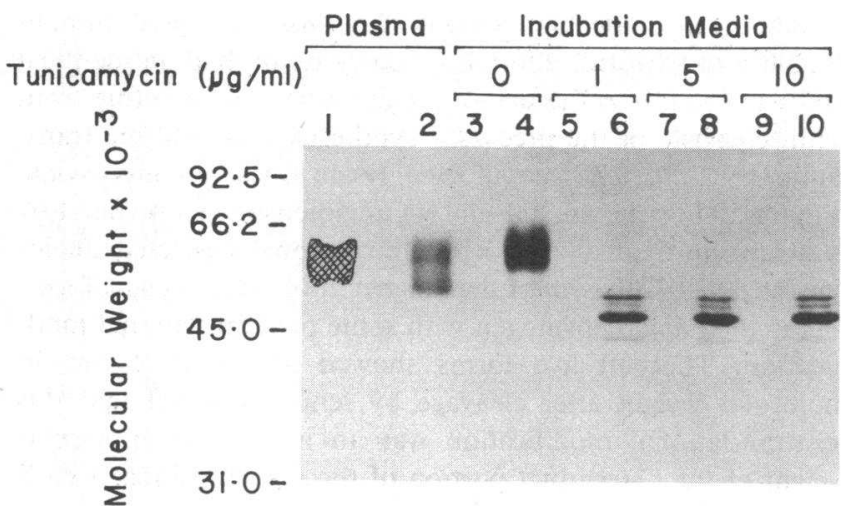

Figure 9. Comparison of pure plasma angiotensinogen with angiotensinogen secreted by Hep G2 cells. ${ }^{35}$ S]Methionine-labeled angiotensinogen secreted by Hep G2 cells incubated in the absence and presence of tunicamycin was immunoprecipitated and subjected to SDS-PAGE and autoradiography. Shown in the figure is an autoradiograph of SDS-PAGE. Lane 1 is a tracing of a Coomassie blue stain of $20 \mu \mathrm{g}$ of pure plasma angiotensinogen run on the same gel, and lane 2 represents ${ }^{125}$ I-iodoangiotensinogen. Lanes 3, 5, 7, and 9 represent immunoprecipitation with nonimmune serum; lanes 4,6 , 8 , and 10 represent immunoprecipitation with antibody $\mathrm{HCl}$.

Chromatography on concanavalin A-Sepharose. Hep G2 cells incubated in the absence of tunicamycin secreted angiotensinogen which was, in part, of higher molecular weight than pure plasma angiotensinogen and ${ }^{125} \mathrm{I}$-iodoangiotensinogen (Fig. 9). This angiotensinogen secreted by Hep G2 cells could be separated into two fractions, one that did not bind and another that did bind to concanavalin A (Fig. 10). The fraction that did not bind to concanavalin $\mathrm{A}$ included the higher molecular weight component of angiotensinogen, whereas the fraction which did bind to concanavalin $A$ had an identical mobility on SDS-PAGE to pure plasma angiotensinogen (Fig. 9).

All forms of angiotensinogen secreted by tunicamycintreated Hep G2 cells failed to bind to concanavalin A (Fig. 10).

Treatment with neuraminidase. For angiotensinogen secreted by Hep G2 cells incubated in the absence of tunicamycin, treatment with neuraminidase caused a considerable reduction in molecular weight, although the extent of heterogeneity was retained (Fig. 11).

For angiotensinogen secreted by tunicamycin-treated cells, the major effect was a specific extinction of the 49,200-mol wt form (Fig. 11). The 49,600-mol wt form was not evident in this experiment. However, the predominant $46,200 \mathrm{~mol} \mathrm{wt}$, and also the 46,800- and 48,100-mol wt forms were essentially unaffected by neuraminidase. The bands of mol wt $<46,200$ in Fig. 11 indicate proteolysis of angiotensinogen by protease contamination of the neuraminidase preparation.

Deglycosylation with TFMS. For angiotensinogen secreted by Hep $\mathrm{G} 2$ cells incubated in the absence of tunicamycin, TFMS produced extensive deglycosylation with marked reduction in both the molecular weight and heterogeneity (Fig. 12).

For angiotensinogen secreted by tunicamycin-treated Hep G2 cells, TFMS caused an extinction of all of the minor forms, with preservation of the predominant 46,200-mol wt form (Fig. 12).

\section{Affinity for Concanavalin A}

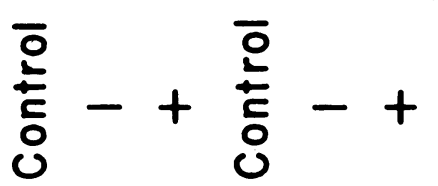

\section{Tunicamycin $--+t+$ 123456}

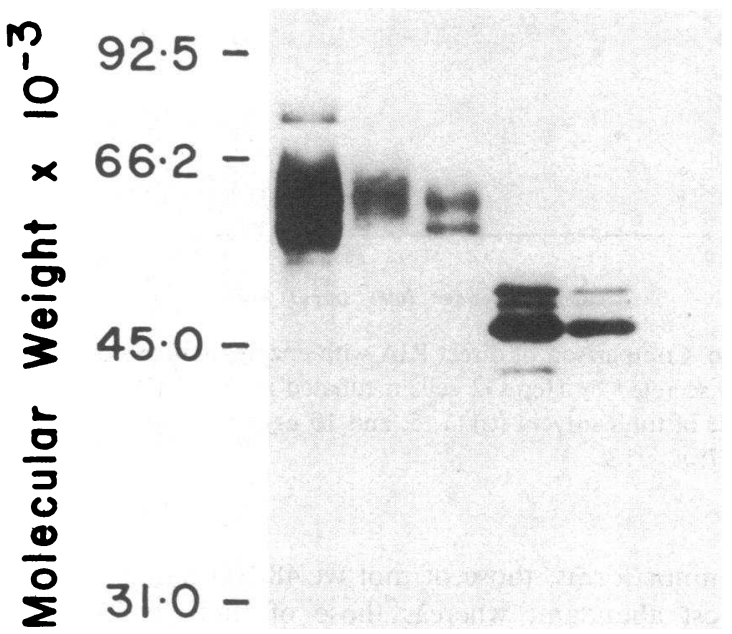

Figure 10. Chromatography of angiotensinogen on concanavalin ASepharose. $\left[{ }^{35}\right.$ S $]$ Methionine-labeled angiotensinogen secreted by Hep G2 cells incubated in the absence or presence of tunicamycin $(5 \mu \mathrm{g} /$ ml) was chromatographed on columns of concanavalin A-Sepharose, then immunoprecipitated (antibody $\mathrm{HCl}$ ) and subjected to SDSPAGE and autoradiography. Shown in the figure are autoradiographs of control (lanes 1 and 4) incubation media, the flow through and wash from the concanavalin A-Sepharose columns (concanavalin A unbound, lanes 2 and 5) and the $0.4 \mathrm{M} \alpha$-methyl-D-mannopyranoside eluate (concanavalin A bound, lanes 3 and 6 ).

Effects of dexamethasone and mestranol. The effects of dexamethasone and mestranol on cell number, incorporation of $\left[{ }^{35} \mathrm{~S}\right]$ methionine and $\left[{ }^{3} \mathrm{H}\right]$ glucosamine, and angiotensinogen production by Hep G2 cells are shown in Table II. Exposure to tunicamycin $(5 \mu \mathrm{g} / \mathrm{ml})$ for $20 \mathrm{~h}$ had no effect on cell number of confluent cultures and the data for cell number shown in Table II represent pooled data for cells incubated in the absence and presence of tunicamycin. Cell counts were performed only on incubations without radioactivity. Thus the data for incorporation of radiolabel and angiotensinogen production are expressed in absolute values per incubation, rather than in relation to cell number. Neither $\left[{ }^{35} S\right]$ methionine or $\left[{ }^{3} \mathrm{H}\right]$ glucosamine had any effect on angiotensinogen production, and Table II presents pooled data for angiotensinogen production by cells incubated in the absence and presence of radiolabel. In the present experiments, the steroid concentrations were chosen so as to determine whether or not these steroids affected the amount and size of angiotensinogen secreted. Definition of the dose-response curve for each steroid is the subject of ongoing experiments in this laboratory.

Dexamethasone $\left(10^{-7}\right.$ and $\left.10^{-6} \mathrm{M}\right)$ caused a two- to fourfold increase in angiotensinogen production by Hep G2 


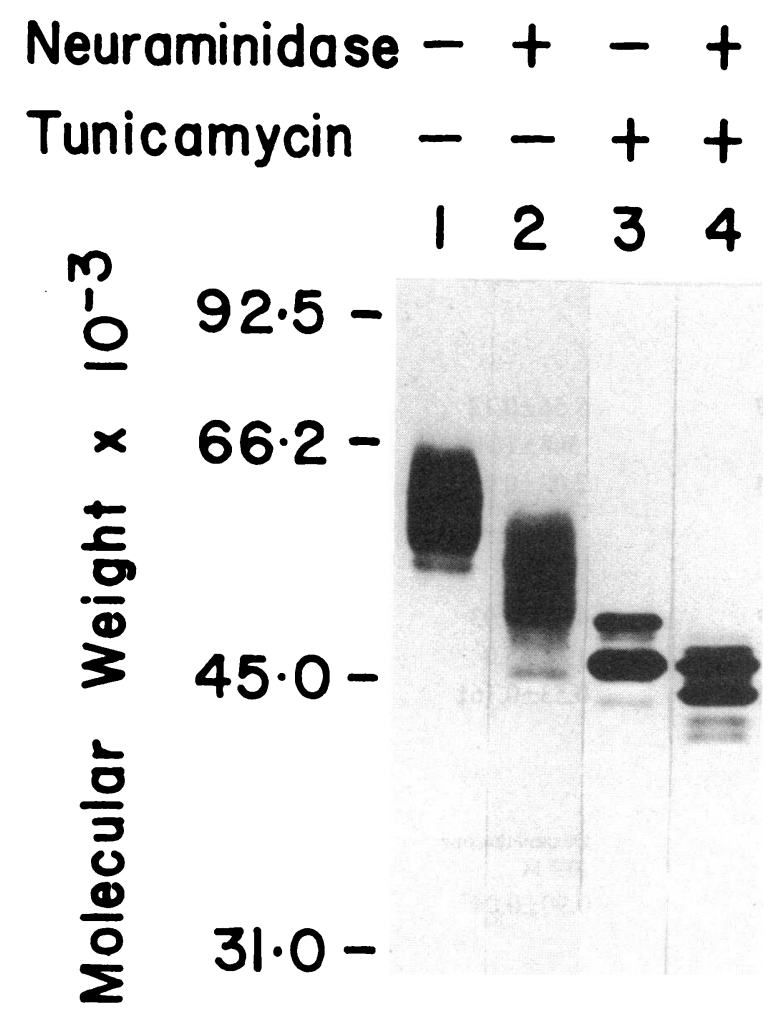

Figure 11. Treatment of angiotensinogen with neuraminidase. $\left[{ }^{35}\right.$ S]Methionine-labeled angiotensinogen secreted by Hep $\mathrm{G} 2$ cells incubated in the absence or presence of tunicamycin $(5 \mu \mathrm{g} / \mathrm{ml})$ was immunoprecipitated (antibody $\mathrm{HCl}$ ), then treated with neuraminidase (see Methods) and subsequently subjected to SDS-PAGE and autoradiography. Shown in the figure are autoradiographs of control (lanes $l$ and 3) and neuraminidase-treated (lanes 2 and 4 ) angiotensinogen

cells, both in the absence and presence of tunicamycin (Table II, Fig. 13). Dexamethasone also produced a $50 \%$ increase in net protein synthesis and secretion as shown by TCA-precipitable $\left[{ }^{35} \mathrm{~S}\right]$ methionine-labeled material $(P<0.001$ for pooled data from experiments A and B, Table II). This was associated with a 60 to $300 \%$ increase in $N$-glycosylation, as shown by tunicamycin suppressible incorporation of $\left[{ }^{3} \mathrm{H}\right]$ glucosamine into TCA-precipitable material $(P=0.05$ for pooled data from experiments $A$ and $B$, Table II).

The smaller increase in angiotensinogen secretion in response to $10^{-6} \mathrm{M}$ dexamethasone, compared with $10^{-7} \mathrm{M}$ dexamethasone (Fig. 13), may be due in part to inhibition of cell growth by the higher concentration of dexamethasone, which was associated with a $25 \%$ reduction in cell number $(P$ $<0.01$, Table II).

In the absence of tunicamycin, mestranol $\left(10^{-7}\right.$ and $10^{-6}$ $M)$ had no significant effect on either angiotensinogen production or incorporation of radiolabel. However, in the presence of tunicamycin, an increase in angiotensinogen production of $86 \%$ for $10^{-7} \mathrm{M}$ mestranol and $57 \%$ for $10^{-6} \mathrm{M}$ mestranol was observed, which was statistically significant for the lower concentration of mestranol (Fig. 13).

Apart from an effect on the abundance of $\left[{ }^{35}\right.$ S $]$ methioninelabeled angiotensinogen, neither dexamethasone or mestranol $\left(10^{-7}\right.$ and $\left.10^{-6} \mathrm{M}\right)$, either in the absence or presence of tunicamycin, had any effect on the electrophoretic (SDS-

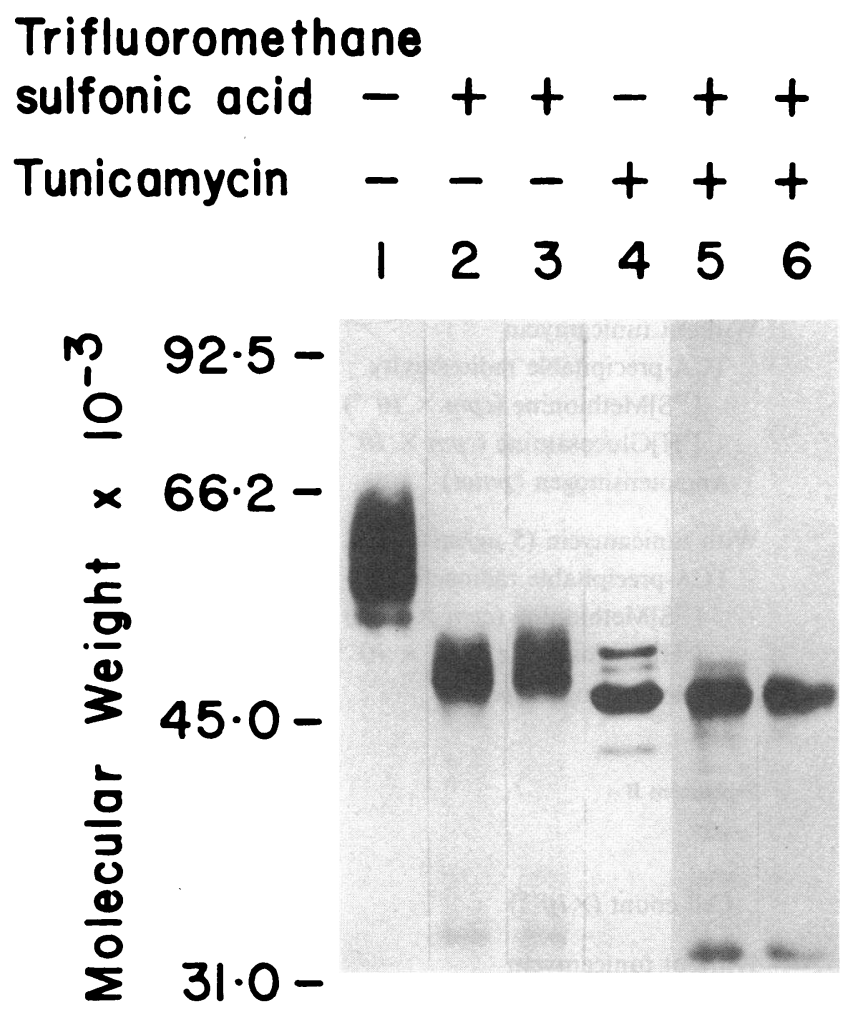

Figure 12. Deglycosylation of angiotensinogen by TFMS.

$\left[{ }^{35} \mathrm{~S}\right]$ Methionine-labeled angiotensinogen secreted by Hep $\mathrm{G} 2$ cells incubated in the absence or presence of tunicamycin $(5 \mu \mathrm{g} / \mathrm{ml})$ was deglycosylated with TFMS, then immunoprecipitated (antibody $\mathrm{HCl}$ ) and subjected to SDS-PAGE and autoradiography. Shown in the figure are autoradiographs of SDS-PAGE of control (lanes 1 and 4) and TFMS-treated (lanes 2, 3,5 and 6) incubation media. For lanes 2 and 5, TFMS was neutralized with pyridine, whereas for lanes 3 and 6, TFMS was neutralized with piperidine.

PAGE) pattern of angiotensinogen immunoprecipitated from incubation media (data not shown). When aliquots of total incubation media were subjected to SDS-PAGE and autoradiography, both mestranol and dexamethasone influenced the pattern of $\left[{ }^{35} \mathrm{~S}\right]$ methionine labeled proteins, as indicated by specific increases in abundance of several proteins (data not shown). Thus both steroids had demonstrable effects on protein synthesis and secretion, and one can conclude that the small effect of mestranol on angiotensinogen secretion was not due to a failure of Hep G2 cells to respond to the steroid.

Column chromatography of incubation media on Sephadex G-200 Superfine revealed only a single peak of angiotensinogen (measured by direct RIA), which eluted in the position of plasma LMW angiotensinogen (data not shown). Similarly, for incubation media of cells incubated with either $10^{-7}$ or $10^{-6} \mathrm{M}$ dexamethasone or mestranol, only one peak of angiotensinogen was apparent. For incubation media with the highest concentration of angiotensinogen (cells stimulated with $10^{-7} \mathrm{M}$ dexamethasone), it could be calculated that any HMW angiotensinogen, if present, would comprise $<1 \%$ of LMW angiotensinogen, the limit of detection being the sensitivity of the angiotensinogen assay.

However, when $0.8 \mathrm{ml}$ of incubation media of Hep G2 cells incubated with $\left[{ }^{35} \mathrm{~S}\right]$ methionine were chromatographed on Sephadex G-200 Superfine, and the whole of each 1.0-ml 
Table II. Effect of Dexamethasone and Mestranol on Cell Number, Incorporation of Radiolabel and Angiotensinogen Production by Hep G2 Cells Incubated in the Absence or Presence of Tunicamycin

\begin{tabular}{|c|c|c|c|c|}
\hline Experiment $\mathrm{A}$ & $n$ & Control & $\begin{array}{l}\text { Dexamethasone } \\
10^{-7} \mathrm{M}\end{array}$ & $\begin{array}{l}\text { Mestranol } \\
10^{-7} \mathrm{M}\end{array}$ \\
\hline Cell count $\left(\times 10^{-6}\right)$ & 4 & $0.97 \pm 0.06$ & $1.29 \pm 0.12$ & $0.87 \pm 0.12$ \\
\hline \multicolumn{5}{|l|}{ Without tunicamycin } \\
\hline \multicolumn{5}{|l|}{ TCA-precipitable radioactivity } \\
\hline$\left[{ }^{35}\right.$ S]Methionine $\left(\mathrm{cpm} \times 10^{-6}\right)$ & 2 & $5.58 \pm 0.37$ & $8.56 \pm 0.12$ & $5.55 \pm 0.41$ \\
\hline$\left[{ }^{3} \mathrm{H}\right]$ Glucosamine $\left(\mathrm{cpm} \times 10^{-3}\right)$ & 2 & $136 \pm 14$ & $568 \pm 104$ & $152 \pm 29$ \\
\hline Angiotensinogen $(\mathrm{pmol})$ & 6 & $0.45 \pm 0.04$ & $2.00 \pm 0.09^{*}$ & $0.56 \pm 0.04$ \\
\hline \multicolumn{5}{|l|}{ With tunicamycin $(5 \mu \mathrm{g} / \mathrm{ml})$} \\
\hline \multicolumn{5}{|l|}{ TCA-precipitable radioactivity } \\
\hline${ }^{35}$ S]Methionine $\left(\mathrm{cpm} \times 10^{-6}\right)$ & 2 & $3.93 \pm 0.27$ & $4.15 \pm 0.93$ & $3.50 \pm 0.25$ \\
\hline$\left[{ }^{3} \mathrm{H}\right]$ Glucosamine $\left(\mathrm{cpm} \times 10^{-3}\right)$ & 2 & $7.6 \pm 0.2$ & $19.5 \pm 5.0$ & $8.7 \pm 0.2$ \\
\hline Angiotensinogen $(\mathrm{pmol})$ & 6 & $0.14 \pm 0.02$ & $0.53 \pm 0.16 \ddagger$ & $0.26 \pm 0.03 \S$ \\
\hline \multicolumn{5}{|l|}{ Experiment B } \\
\hline & $n$ & Control & $\begin{array}{l}\text { Dexamethasone } \\
10^{-6} \mathrm{M}\end{array}$ & $\begin{array}{l}\text { Mestranol } \\
10^{-6} \mathrm{M}\end{array}$ \\
\hline Cell count $\left(\times 10^{-6}\right)$ & 4 & $1.20 \pm 0.04$ & $0.90 \pm 0.04^{\prime \prime}$ & $1.10 \pm 0.06$ \\
\hline \multicolumn{5}{|l|}{ Without tunicamycin } \\
\hline \multicolumn{5}{|l|}{ TCA-precipitable radioactivity } \\
\hline$\left[{ }^{35}\right.$ S]Methionine $\left(\mathrm{cpm} \times 10^{-6}\right)$ & 2 & $4.22 \pm 0.31$ & $6.23 \pm 0.30$ & $4.22 \pm 0.59$ \\
\hline$\left[{ }^{3} \mathrm{H}\right]$ Glucosamine $\left(\mathrm{cpm} \times 10^{-3}\right)$ & 2 & $101 \pm 2$ & $161 \pm 20$ & $82 \pm 0$ \\
\hline Angiotensinogen ( $p m o l)$ & 6 & $0.52 \pm 0.06$ & $1.05 \pm 0.17 \S$ & $0.52 \pm 0.08$ \\
\hline \multicolumn{5}{|l|}{ With tunicamycin $(5 \mu \mathrm{g} / \mathrm{ml})$} \\
\hline \multicolumn{5}{|l|}{ TCA-precipitable radioactivity } \\
\hline$\left[{ }^{35}\right.$ S]Methionine $\left(\mathrm{cpm} \times 10^{-6}\right)$ & 2 & $2.18 \pm 0.17$ & $3.39 \pm 0.16$ & $3.16 \pm 0.26$ \\
\hline$\left[{ }^{3} \mathrm{H}\right]$ Glucosamine $\left(\mathrm{cpm} \times 10^{-3}\right)$ & 2 & $4.2 \pm 0.3$ & $9.2 \pm 0.1$ & $6.9 \pm 1.1$ \\
\hline Angiotensinogen $(\mathrm{pmol})$ & 6 & $0.14 \pm 0.03$ & $0.35 \pm 0.04^{\prime \prime}$ & $0.22 \pm 0.06$ \\
\hline
\end{tabular}

Data presented as mean \pm SE; $n=$ number of incubations. Values for incorporation of radiolabel and angiotensinogen production represent an $8 \mathrm{~h}$ incubation. ${ }^{*} P<0.001 ; \ddagger P<0.05 ; \S P<0.02 ; " P<0.01 ;$ compared with control.

column fraction was immunoprecipitated and subjected to SDS-PAGE and autoradiography, it was evident that both mestranol and dexamethasone stimulated the secretion of HMW angiotensinogen (eluting just after the column void volume) (Fig. 14). Moreover, this HMW angiotensinogen migrated on SDS-PAGE in a position identical to LMW angiotensinogen, providing direct evidence that HMW angiotensinogen is an aggregate of LMW angiotensinogen. As a negative control, when immunoprecipitation was performed with nonimmune serum, neither HMW or LMW angiotensinogen was immunoprecipitated from incubation media of Hep G2 cells incubated in the presence of $10^{-6} \mathrm{M}$ dexamethasone (data not shown).

\section{Discussion}

The present study provides several lines of evidence in support of the conclusion that all forms of angiotensinogen are derived from a single precursor, and that the heterogeneity of secreted angiotensinogen represents differences in posttranslational processing. This posttranslational processing includes both $\mathrm{N}$ - glycosylation and $O$-glycosylation, and also the formation of high molecular weight complexes by association either between LMW angiotensinogen molecules or between LMW angiotensinogen and some other protein(s) whose secretion by hepatocytes is stimulated by dexamethasone and mestranol. In the present discussion, although our results show HMW angiotensinogen to be an aggregate of LMW angiotensinogen (discussed below), we will continue to use the term HMW angiotensinogen to refer to that species of angiotensinogen with reduced mobility on non-denaturing PAGE, and elution close to the void volume on Sephadex G-200 column chromatography.

Characterization of antibodies. The first requirement of our study was the demonstration that our antibodies recognize all forms of angiotensinogen. Both polyclonal and both monoclonal antibodies recognized both HMW and LMW plasma angiotensinogen. In addition, both polyclonal and both monoclonal antibodies recognized all forms of angiotensinogen secreted by Hep G2 cells incubated in the absence or presence of tunicamycin. Thus all four antibodies recognized both glycosylated and nonglycosylated angiotensinogen.

Our antibodies obviously differ from the polyclonal antibody 


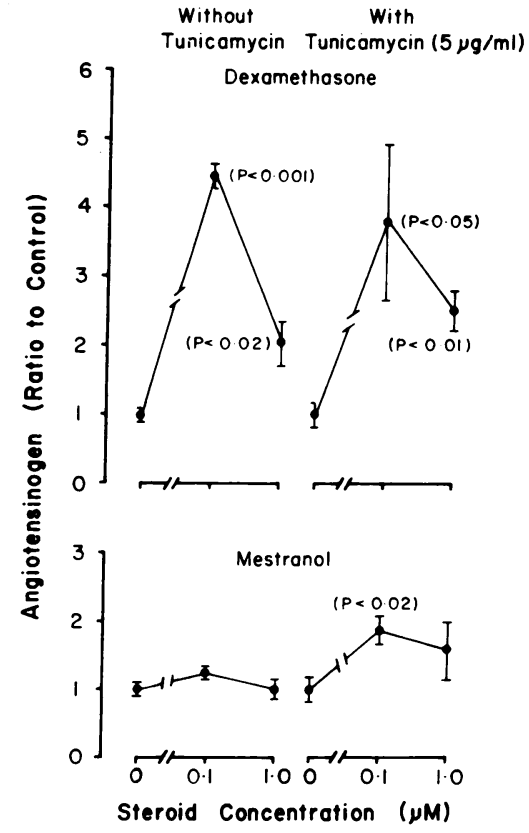

Figure 13. Effect of dexamethasone and mestranol on angiotensinogen secretion by Hep G2 cells incubated in the absence or presence of tunicamycin. Angiotensinogen production per $8 \mathrm{~h}$ of incubation is expressed as ratio to control. Each data point represents the mean $( \pm \mathrm{SE})$ for six incubations. See Table II for absolute values.

of Eggena et al. $(11,12)$. All of our antibodies recognized HMW plasma angiotensinogen, whereas the antibody of Eggena et al. did not $(11,12)$. The particular specificity of the antibody of Eggena et al. $(11,12)$ may relate to the fact that it was raised against a preparation of angiotensinogen which was $\sim 50 \%$ pure.

In the present experiments, immunoprecipitation of angiotensinogen secreted by Hep G2 cells by monoclonal antibodies was less than quantitative (Fig. 7) because only small amounts of antibody were available. These monoclonal antibodies have not, as yet, been prepared in large scale. Although recognizing both HMW and LMW plasma angiotensinogen and both glycosylated and nonglycosylated angiotensinogen secreted by Hep G2 cells, these monoclonal antibodies did not recognize either the angiotensinogen precursor synthesized by cell-free translation or des-AI-angiotensinogen resulting from renin cleavage of the precursor (Fig. 3). In addition, we have shown that these antibodies do not recognize des-AI-angiotensinogen resulting from renin cleavage of either glycosylated or nonglycosylated angiotensinogen secreted by Hep G2 cells (Bouhnik, J., manuscript in preparation). In contrast, both polyclonal antibodies recognized all forms of angiotensinogen including the precursor, and glycosylated and nonglycosylated des-AIangiotensinogen. These data suggest that the monoclonal antibodies recognize the $\mathrm{N}$-terminal region of the angiotensinogen molecule, which may be subject to steric hindrance by the signal peptide, and also to some conformational change following cleavage by renin.

Characterization of plasma angiotensinogen. The studies of Gordon and Sachin $(7,8)$ suggest that the HMW angiotensinogen demonstrated by gel filtration is equivalent to the angiotensinogen with reduced mobility on PAGE. Several studies suggest that the angiotensinogen with slower mobility on PAGE is unlikely to reflect a difference in charge $(10,14$, 15). Tewksbury and Dart (18) have shown that HMW and LMW angiotensinogen differ in their hydrodynamic radii. These authors have also provided evidence that HMW angiotensinogen is composed of multiple polypeptide chains whose separation required alkylation, reduction, and chromatography in $6 \mathrm{M}$ guanidine hydrochloride (17). However, recovery of angiotensinogen from this procedure was only $10 \%$ and they were unable to determine whether the component of HMW angiotensinogen eluting in the position of LMW angiotensinogen was identical to LMW angiotensinogen.

The present study demonstrates that HMW and LMW angiotensinogen are immunologically similar, in that they were recognized by both polyclonal and both monoclonal antibodies. In the direct RIA of angiotensinogen, all four antibodies provided values for immunoreactive HMW angiotensinogen which were less than the values provided by the enzymatic assay. In contrast, direct RIA of LMW angiotensinogen, using all four antibodies, was in good agreement with the enzymatic assay. Given that HMW angiotensinogen caused displacement of ${ }^{125}$ I-iodoangiotensinogen which was parallel to that for LMW and pure plasma angiotensinogen, and that antibody $\mathrm{HCl}$ was able to quantitatively immunoprecipitate HMW angiotensinogen, our data suggest that HMW angiotensinogen has a lower affinity for our antibodies than LMW angiotensinogen. This is consistent with our evidence that HMW angiotensinogen is an aggregate of LMW angiotensinogen. Aggregation of LMW angiotensinogen molecules would mask antigenic sites, thus reducing the apparent affinity (relative to LMW angiotensinogen) of HMW angiotensinogen for an antibody. That the monoclonal antibodies had a lower apparent affinity for HMW angiotensinogen than the polyclonal antibodies is consistent with the fact that monoclonal antibodies recognize only a single antigenic site, whereas polyclonal antibodies may recognize more than one antigenic site on the angiotensinogen molecule.

Our evidence that HMW angiotensinogen represents an aggregate of LMW angiotensinogen raises the question whether the enzymatic assay provides an accurate measure of HMW angiotensinogen. If reduced affinity of antibodies for HMW angiotensinogen represents masking of antigenic sites within the aggregate, then one would expect that the site of renin cleavage would be similarly masked. It is possible that incubation for $3 \mathrm{~h}$ at $37^{\circ} \mathrm{C}$ and $\mathrm{pH} 5.7$ during the enzymatic assay may cause the sites of cleavage to become accessible to renin. However, the validity of the enzymatic assay of HMW angiotensinogen remains to be established. Consequently, any attempt to characterize the kinetics of the renin-HMW angiotensinogen reaction must await such validation. That our recoveries of plasma angiotensinogen from Sephadex G-200 column chromatography were consistently over $100 \%$ (see Methods) suggests that some disaggregation of HMW angiotensinogen occurred during chromatography and emphasizes the doubtful validity of the enzymatic assay of HMW angiotensinogen.

Characterization of precursor and secreted forms of angiotensinogen. In the present study, the different forms of angiotensinogen secreted by Hep G2 cells have been characterized by several criteria. These include immunoprecipitation by both polyclonal and both monoclonal antibodies (Fig. 7), mobility on SDS-PAGE, and cleavage by renin. The des-AI-angiotensinogen generated by renin cleavage of the precursor synthesized 

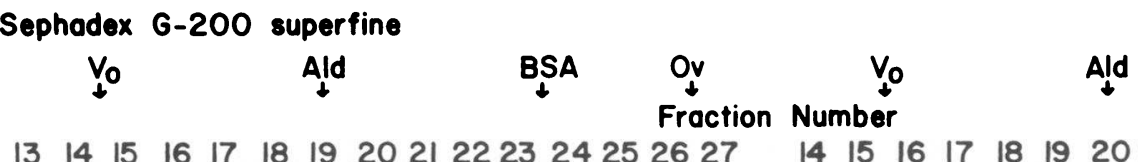

BȘA

Ov

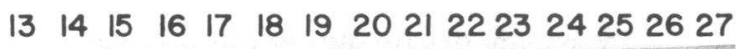

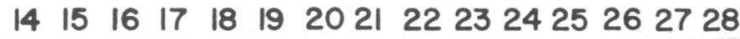
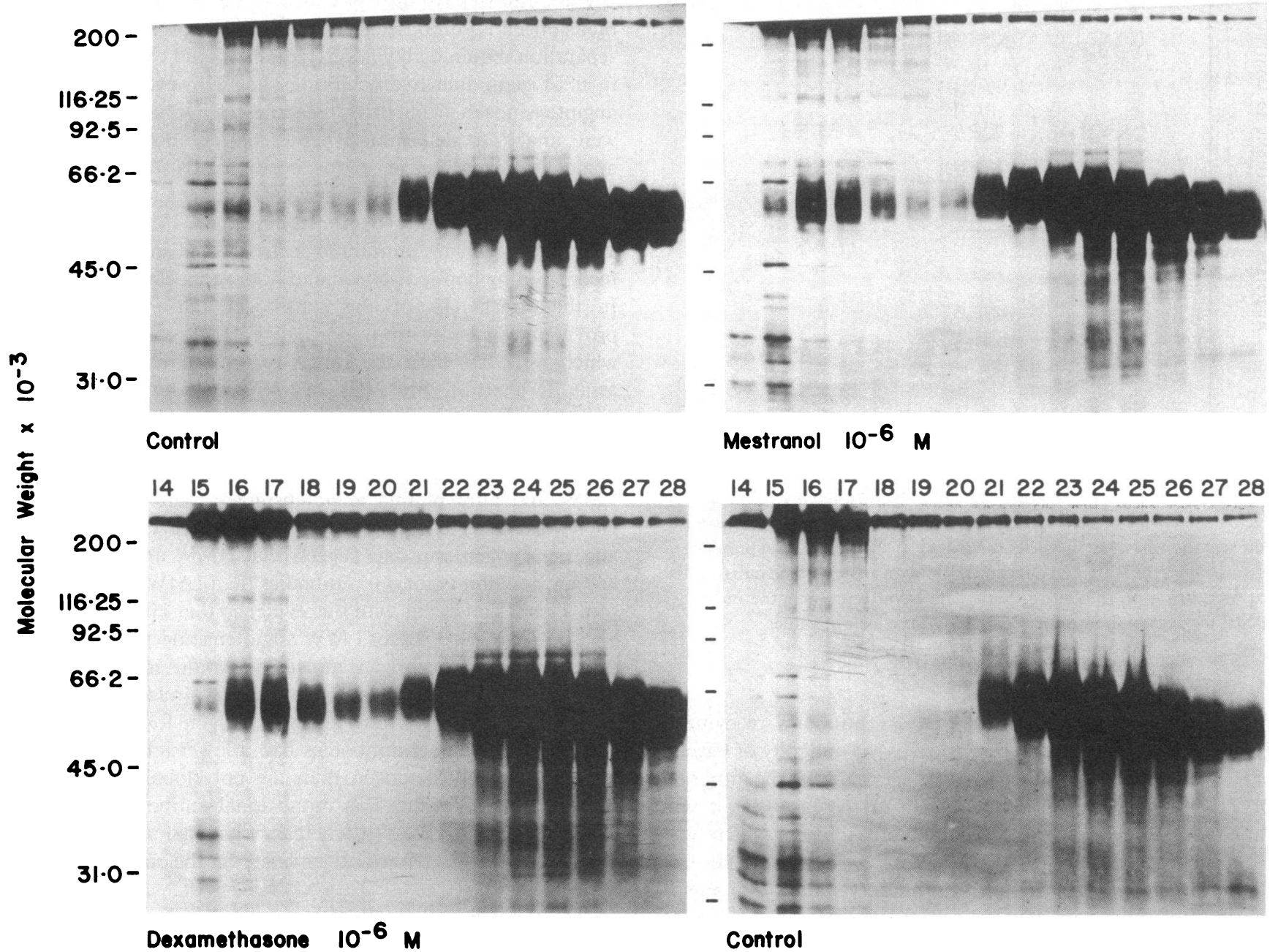

$\begin{array}{lllllllllllllll}14 & 15 & 16 & 17 & 18 & 19 & 20 & 21 & 22 & 23 & 24 & 25 & 26 & 27 & 28\end{array}$

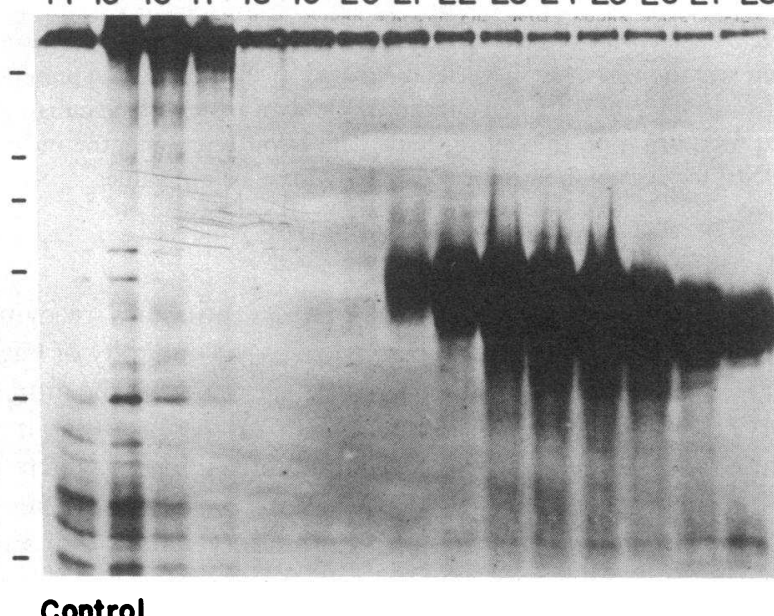

Figure 14. Effect of dexamethasone and mestranol on

$\left[{ }^{35} \mathrm{~S}\right]$ methionine-labeled angiotensinogen secreted by Hep G2 cells incubated in the absence of tunicamycin. Incubation media $(0.8 \mathrm{ml})$ were chromatographed on columns of Sephadex G-200 Superfine and the column fractions $(1.0 \mathrm{ml}$ ) immunoprecipitated (antibody $\mathrm{HCl}$ ) then subjected to SDS-PAGE and autoradiography. Shown in the figure are the autoradiographs of the SDS-PAGE of the column fractions indicated in the figure. Similar results were obtained for Hep G2 cells incubated in the presence of $10^{-7} \mathrm{M}$ dexamethasone or mestranol. $V_{0}$, column void volume; Ald, aldolase, mol wt 158,000; BSA, bovine serum albumin, mol wt 67,000; Ov, ovalbumin, mol wt

by cell-free translation had a mobility identical to that of desAI-angiotensinogen produced by renin treatment of nonglycosylated angiotensinogen secreted by tunicamycin-treated Hep G2 cells (Fig. 8). These results have enabled us to confidently identify both the precursor and secreted forms of angiotensinogen. Angiotensinogen is the only known substrate of renin. Thus, the cleavage by renin of the different forms of angiotensinogen characterized in this study represents a highly specific method for their identification. The relative resistance of the angiotensinogen precursor to cleavage by renin (Fig. 8) was probably due to inhibition of renin by the hemoglobin in the
43,000 . The autoradiographs show a HMW $(>200,000)$ protein which eluted in all column fractions, though it was most abundant in the column void volume. This protein does not represent angiotensinogen since it was also immunoprecipitated by nonimmune serum, and was not extinguished by preabsorption of the antibody with pure angiotensinogen. This protein showed a decrease in molecular weight when secreted by tunicamycin-treated cells, indicating $N$-glycosylation, and is considered to be fibronectin, a glycoprotein composed of two similar disulfide-bonded subunits, each with an approximate mol wt of 220,000 .

lysate (40), although it is also possible that the signal peptide of the precursor may interfere with the action of renin.

We have previously reported that cell-free translation of rat liver RNA revealed two angiotensinogen precursors $(1,27)$. Therefore, to verify our finding of only one angiotensinogen precursor synthesized by cell-free translation of human liver RNA, we fractionated mRNA on an agarose gel in the presence of $12.5 \mathrm{mM}$ methylmercury hydroxide. The results confirmed our finding of only one angiotensinogen precursor (Fig. 4). The estimated size of angiotensinogen mRNA (2,000 bases; Fig. 4) is in agreement with the results obtained by Kageyama 
et al. (28) who used the technique of Northern blotting. Moreover, our estimate of $46,200 \mathrm{~mol} w \mathrm{w}$ for nonglycosylated mature angiotensinogen is in agreement with the mol wt of 49,770 deduced from the cDNA sequence by Kageyama et al. (28).

From their analysis of the nucleotide sequence of angiotensinogen mRNA and its corresponding amino acid sequence, Kageyama et al. (28) found the human angiotensinogen precursor to be encoded by two mRNAs which differ only in the length of their 3'-untranslated regions. These authors also found two methionine residues in the putative signal peptide, at positions -24 and -33 , and they speculated that both may act as sites of initiation of translation and that the second site (-24) may be predominant. Our evidence for one precursor synthesized by cell-free translation indicates that only one of the two potential initiation sites is used. In the present study, the difference in apparent molecular weight $(3,800)$ between the precursor $(50,000)$ and the mature nonglycosylated angiotensinogen $(46,200)$ suggests that the signal peptide is 33 rather than 24 amino acids in length, and that the methionine at -33 is the site of initiation of translation. However, the limitations of SDS-PAGE in quantifying molecular weight prevent us from excluding the alternative potential initiation site.

Because our polyclonal antibodies recognize all forms of angiotensinogen, and yet identify only one angiotensinogen precursor synthesized by cell-free translation of RNA prepared from Hep G2 cells or liver, all forms of secreted and plasma angiotensinogen must be derived from this precursor. $\mathrm{Al}$ though the liver RNA used in the present experiments was obtained from males, we have found that plasma of normal males contains an amount of HMW angiotensinogen (4.6$5.1 \%$ by enzymatic assay) similar to that in plasma of normal females $(2.3-4.1 \%)$. Thus, the present experiments would have been able to identify a second mRNA coding for HMW angiotensinogen if it existed. Our evidence for a single precursor is supported by the preliminary finding of Kageyama et al. (28) that the human genome contains only a single angiotensinogen gene: the two angiotensinogen mRNAs arise from the single gene by utilization of two polyadenylation signals (28).

Glycosylation of angiotensinogen. The effect of tunicamycin on angiotensinogen secreted by Hep G2 cells indicates that the major posttranslational modification to angiotensinogen is $\mathrm{N}$-glycosylation, which is the major determinant of the heterogeneity of angiotensinogen on SDS-PAGE. Our evidence for $N$-glycosylation of angiotensinogen is supported by its aminoacid sequence which contains four potential sites of $\mathrm{N}$-glycosylation (28).

As shown in Fig. 9, angiotensinogen secreted by Hep G2 cells, although similarly heterogeneous on SDS-PAGE, was of higher mean molecular weight than pure plasma angiotensinogen. Concanavalin A-Sepharose chromatography of angiotensinogen secreted by Hep G2 cells (Fig. 10) resolved two components. One component, of molecular weight similar to plasma angiotensinogen (Fig. 9), bound to concanavalin A, as has been shown previously for plasma angiotensinogen $(9,16)$. A second component of higher molecular weight did not bind to concanavalin $\mathrm{A}$, and probably represents angiotensinogen with increased peripheral addition to its oligosaccharide units, of residues with low affinity for concanavalin $\mathrm{A}$, such as sialic acid, galactose and $N$-acetylgalactosamine (41-43). In support of this interpretation, treatment with neuraminidase caused an appreciable reduction in the molecular weight of angiotensinogen (Fig. 11). Plasma angiotensinogen normally contains sialic acid, which contributes to its acidic isoelectric point $(15,20)$. However, sialic acid is not a major determinant of the heterogeneity of human angiotensinogen, as determined by SDSPAGE (Fig. 11) or isoelectric profile (15).

In agreement with the present results, we have previously shown that rat hepatoma cells glycosylate angiotensinogen more extensively than rat hepatocytes in primary culture (27). This may relate to differences in cell growth rate, since a similar growth-dependent alteration in glycosylation mechanisms has been previously reported for other cell systems $(44,45)$.

The present studies with tunicamycin demonstrate that $N$ glycosylation of angiotensinogen is essential neither for its synthesis, processing and secretion, nor its cleavage by renin. We have previously discussed the possible significance of the inhibition of protein synthesis by tunicamycin (27). Tunicamycin was also valuable in unmasking a previously unsuspected additional type of posttranslational processing of angiotensinogen. The increase in molecular weight (up to 3,400 from $46,200-49,600$ ) due to this additional posttranslational event suggested $O$-glycosylation, and this was confirmed by the specific modification by TFMS of these higher molecular weight forms of angiotensinogen secreted by tunicamycin treated Hep G2 cells (Fig. 12). This interpretation is also supported by the results of digestion with neuraminidase (Fig. 11) and chromatography on concanavalin A (Fig. 10). The higher molecular weight minor forms of angiotensinogen secreted by tunicamycin-treated cells were specifically modified by neuraminidase, suggesting that they possess sialic acid residues. The failure of these $\boldsymbol{O}$-glycosylated forms of angiotensinogen to bind to concanavalin $\mathrm{A}$ indicates that they do not contain saccharide residues with affinity for concanavalin A. These data suggest that the $O$-linked oligosaccharide units of angiotensinogen may resemble the $O$-linked tetrasaccharide units of fetuin, erythrocyte glycophorin and human chorionic gonadotropin (46-48). These tetrasaccharide units are composed of a serine-linked $\mathrm{N}$-acetylgalactosamine residue attached to a galactose residue, each of which is attached to a sialic acid residue. Ascertainment whether $\boldsymbol{O}$-glycosylation of angiotensinogen is limited to Hep G2 cells or also occurs in vivo, will require appropriate studies of pure plasma angiotensinogen, or studies of human hepatocytes in primary culture.

The effect of TFMS on $\left.{ }^{35} \mathrm{~S}\right]$ methionine-labeled angiotensinogen secreted by Hep $\mathrm{G} 2$ cells incubated in the absence of tunicamycin (Fig. 12) provided direct support for our studies of the precursor synthesized by cell-free translation, and the effects of tunicamycin on secreted angiotensinogen. It was clearly evident, from the effects of TFMS, that the basis of the heterogeneity of secreted angiotensinogen was variation in glycosylation. In particular, there was no evidence for protein heterogeneity. The failure of TFMS to completely deglycosylate angiotensinogen (Fig. 12) is due to the inability of TFMS to remove asparagine- and serine-linked $N$-acetylglucosaminyl and $N$-acetylgalactosaminyl residues. In addition, some galactosyl residues located in serine linked oligosaccharide units may be resistant to removal by TFMS $(36,37)$.

As we have previously shown for rat angiotensinogen (27), renin was able to cleave both the nonglycosylated angiotensinogen precursor synthesized by cell-free translation, and nonglycosylated and $O$-glycosylated secreted forms of angiotensi- 
nogen. Further studies will be necessary to define the role of glycosylation in the kinetics of the renin-angiotensinogen reaction, particularly in view of evidence that asparagine at position 14 of angiotensinogen is glycosylated (19).

Effect of dexamethasone and mestranol. Both glucocorticoids and estrogens increase plasma levels of angiotensinogen and the proportion of which is of high molecular weight $(7,8$, $11,12,17,18)$. In agreement with our previous study of rat hepatoma cells (33), dexamethasone caused a several-fold increase in angiotensinogen production by Hep G2 cells. In contrast, mestranol caused a smaller increase in angiotensinogen production which was only evident for tunicamycin-treated Hep G2 cells (Fig. 13). That Hep G2 cells responded to mestranol was clearly shown by the change in electrophoretic (SDS-PAGE) pattern of [ $\left.{ }^{35} \mathrm{~S}\right]$ methionine-labeled protein secreted into the incubation media, including an increase in amount of HMW angiotensinogen (Fig. 14).

The design of our present study of steroid effects on angiotensinogen production was based upon our previous study of glucocorticoid stimulation of angiotensinogen production by rat hepatoma cells (33). In a study of the time course of steroid effect on angiotensinogen production by Hep G2 cells, stimulation by $10^{-7} \mathrm{M}$ dexamethasone was evident within $24 \mathrm{~h}$ but no effect of $10^{-7} \mathrm{M}$ mestranol was evident at either 24 or $72 \mathrm{~h}$. We have been similarly unable to achieve a stimulation by estrogens of angiotensinogen production by rat hepatoma cells (Coezy, E., unpublished results). Nasjletti and Masson (49) have shown that angiotensinogen production by perfused rat liver increases within $4 \mathrm{~h}$ in response to stilbestrol. Krakoff and Eisenfeld (50) found that the estrogen-induced increase in plasma levels of angiotensinogen in rats was only evident in sexually mature rats, and could be prevented by hypophysectomy. Hep G2 cells are derived from a primary liver carcinoma obtained from a 15-year-old Caucasian boy (51), presumably sexually mature. Thus, the failure of angiotensinogen production by Hep $\mathrm{G} 2$ cells to increase in response to mestranol (in the absence of tunicamycin) may represent the absence of some essential pituitary factor, in addition to the possibility of changes in cellular responsiveness accompanying transformation and long-term culture.

Neither dexamethasone nor mestranol influenced the electrophoretic (SDS-PAGE) pattern of $\left[{ }^{35} \mathrm{~S}\right]$ methionine-labeled angiotensinogen secreted by Hep $\mathrm{G} 2$ cells incubated in the absence or presence of tunicamycin. Thus, there was no obvious effect of either steroid on the size of angiotensinogen, when analyzed by this denaturing technique. To unmask an effect of steroid on the size of the native angiotensinogen, it was necessary to first chromatograph the incubation media on columns of Sephadex G-200 Superfine (Fig. 14). A precise quantitative estimate of the amount of HMW angiotensinogen secreted by Hep G2 cells was not possible, in that the levels were below the sensitivity of the assay. However, immunoprecipitation of both HMW and LMW angiotensinogen from the column fractions was quantitative, as shown by our studies of plasma angiotensinogen (Fig. 1). Thus the autoradiograms in Fig. 14 faithfully represent all forms of angiotensinogen secreted by Hep G2 cells and clearly demonstrate that the secretion of HMW angiotensinogen is stimulated by both dexamethasone and mestranol.

By immunoprecipitating the column fractions, it would be expected that if HMW angiotensinogen contained newly synthesized $\left({ }^{35} \mathrm{~S}\right]$ methionine-labeled) proteins other than LMW angiotensinogen, then these would also be immunoprecipitated and evident in the autoradiograms. Both dexamethasone and mestranol did appear to increase the abundance of proteins other than LMW angiotensinogen, which were immunoprecipitated from those fractions containing HMW angiotensinogen. However, we are unable, from the present data, to determine whether these proteins are components of the HMW angiotensinogen complex. The autoradiograms suggest that, of those $\left[{ }^{35}\right.$ S]methionine-labeled proteins with mol wt 30,000-200,000 on SDS-PAGE, LMW angiotensinogen is the major component of HMW angiotensinogen (Fig. 14).

These studies provide direct support for the findings of Tewksbury and Dart (17), cited above. Although we have been unable to quantitate the amount of HMW angiotensinogen secreted by Hep G2 cells, the results shown in Fig. 14 do allow us to conclude that HMW angiotensinogen is an aggregate. This conclusion is supported by our studies of the immunoreactivity of HMW angiotensinogen and our characterization of the precursor and secreted forms of angiotensinogen. The HMW angiotensinogen aggregate is dissociable by boiling in SDS and 2-mercaptoethanol, and represents an association either between LMW angiotensinogen molecules or between LMW angiotensinogen and some other protein(s) whose secretion by hepatocytes is stimulated by dexamethasone and mestranol.

\section{Acknowledgments}

This work was supported by INSERM (France) grant CRL 824022 and the Association Claude Bernard. D. J. Campbell is recipient of a C. J. Martin Fellowship of the National Health and Medical Research Council of Australia. We are grateful to Dr. F. X. Galen for the gift of pure human renin, to Dr. B. Pau for the provision of the monoclonal antibodies, and to Nicole Braure for typing the manuscript.

\section{References}

1. Campbell, D. J., J. Bouhnik, J. Menard, and P. Corvol. 1984. Identity of angiotensinogen precursors of rat brain and liver. Nature (Lond.). 308:206-208.

2. Skeggs, L. T., J. R. Kahn, K. E. Lentz, and N. P. Shumway. 1957. The preparation, purification, and amino acid sequence of a polypeptide renin substrate. J. Exp. Med. 106:439-453.

3. Skeggs, L. T., K. E. Lentz, J. R. Kahn, and N. P. Shumway. 1958. The synthesis of a tetradecapeptide renin substrate. J. Exp. Med. 108:283-297.

4. Bouhnik, J., E. Clauser, D. Strosberg, J. P. Frenoy, J. Menard, and P. Corvol. 1981. Rat angiotensinogen and des(angiotensin I)angiotensinogen: purification, characterization, and partial sequencing. Biochemistry. 20:7010-7015.

5. Tewksbury, D. A., R. A. Dart, and J. Travis. 1981. The amino terminal amino acid sequence of human angiotensinogen. Biochem. Biophys. Res. Commun. 99:1311-1315.

6. Lentz, K. E., L. T. Skeggs, K. R. Woods, J. R. Kahn, and N. P. Shumway. 1956. The amino acid composition of hypertensin II and its biochemical relationship to hypertensin I. J. Exp. Med. 104:183191.

7. Gordon, D. B., I. N. Sachin, and V. N. Dodd. 1976. Heterogeneity of renin substrate in human plasma: effect of pregnancy and oral contraceptives. Proc. Soc. Exp. Biol. Med. 153:314-318.

8. Gordon, D. B., and I. N. Sachin. 1977. Chromatographic separation of multiple renin substrates in women: effect of pregnancy and oral contraceptives. Proc. Soc. Exp. Biol. Med. 156:461-464.

9. Printz, M. P., J. M. Printz, and R. T. Dworschack. 1977. Human angiotensinogen. Purification, partial characterization, and a comparison with animal prohormones. J. Biol. Chem. 252:1654-1662. 
10. Printz, M. P., J. M. Printz, J. A. Lewicki, and T. Gregory. 1977. Resolution of multiple forms of human angiotensinogen. Isoelectric focusing heterogeneity profile analysis. Circ. Res. 41(Suppl. 2): II-37-II-43.

11. Eggena, P., J. D. Barrett, H. Hidaka, C. L. Chu, C. Thananopavarn, M. S. Golub, and M. P. Sambhi. 1977. A direct radioimmunoassay for human renin substrate and identification of multiple substrate types in plasma. Circ. Res. 41(Suppl. 2):II-34-II-37.

12. Eggena, P., H. Hidaka, J. D. Barrett, and M. P. Sambhi. 1978. Multiple forms of human plasma renin substrate. J. Clin. Invest. 66: 367-372.

13. Dorer, F. E., K. E. Lentz, J. R. Kahn, M. Levine, and L. T. Skeggs. 1978. Purification of human renin substrate. Anal. Biochem. 87:11-18.

14. Lentz, K. E., F. E. Dorer, J. R. Kahn, M. Levine, and L. T Skeggs. 1978. Multiple forms of renin substrate in human plasma Clin. Chim. Acta. 83:249-257.

15. Faiers, A. A., A. Y. Loh, and D. H. Osmond. 1978. Microheterogeneity and sialic acid in human plasma angiotensinogens in various physiological states. Can. J. Biochem. 56:892-899.

16. Kokubu, T., K. Hiwada, and Y. Sogo. 1980. Isolation and characterization of human renin substrate. Jpn. Circ. J. 44:274-282.

17. Tewksbury, D. A., and R. A. Dart. 1981. Molecular weight studies on high-molecular weight human angiotensinogen. In Heterogeneity of Renin and Renin-Substrate. M. P. Sambhi, editor. Elsevier/ North Holland, New York. 261-270.

18. Tewksbury, D. A., and R. A. Dart. 1982. High molecular weight angiotensinogen levels in hypertensive pregnant women. $\mathrm{Hy}$ pertension (Dallas). 4:729-734. 2728 .

19. Tewksbury, D. A. 1983. Angiotensinogen. Fed. Proc. 42:2724-

20. Tewksbury, D. A. 1984. Studies on the purification and characterization of human angiotensinogen. In Topics in Pathophysiology of Hypertension. H. Villarreal, and M. P. Sambhi, editors. Martinus Nijhoff, Boston. 419-429.

21. Genain, C., J. Bouhnik, D. Tewksbury, P. Corvol, and J. Menard. 1984. Characterization of plasma and cerebrospinal fluid human angiotensinogen and des-angiotensin I-angiotensinogen by direct radioimmunoassay. J. Clin. Endocrinol. Metab. 59:478-484.

22. Skeggs, L. T., K. E. Lentz, H. Hochstrasser, and J. R. Kahn. 1963. The purification and partial characterization of several forms of hog renin substrate. J. Exp. Med. 118:73-98.

23. Hilgenfeldt, U., and E. Hackenthal. 1979. Purification and characterization of rat angiotensinogen. Biochim. Biophys. Acta. 579: 375-385.

24. Hilgenfeldt, U., and E. Hackenthal. 1982. Separation and characterization of two different species of rat angiotensinogen. Biochim. Biophys. Acta. 708:335-342.

25. Voigt, J., B. Wittmann-Liebold, and H. Koster. 1982. Purification and characterization of two forms of rat plasma proangiotensin. Eur. J. Biochem. 122:183-191.

26. Printz, M. P., and R. A. Skidgel. 1981. Relationship of microheterogeneity and sialic acid content on reactivity of plasma angiotensinogen with homologous kidney renin. In Heterogeneity of Renin and Renin-Substrate. M. P. Sambhi, editor. Elsevier/North Holland, New York. 271-279.

27. Campbell, D. J., J. Bouhnik, E. Coezy, F. Pinet, E. Clauser, J. Menard, and P. Corvol. 1984. Characterization of precursor and secreted forms of rat angiotensinogen. Endocrinology. 114:776-785.

28. Kageyama, R., H. Ohkubo, and S. Nakanishi. 1984. Primary structure of human preangiotensinogen deduced from the cloned cDNA sequence. Biochemistry. 23:3603-3609.

29. Knowles, B. B., C. C. Howe, and D. Aden. 1980. Human hepatocellular carcinoma cell lines secrete the major plasma proteins and hepatitis B surface antigen. Science (Wash. DC). 209:497-499.

30. Chirgwin, J. M., A. E. Przybyla, R. J. MacDonald, and W. J.
Rutter. 1979. Isolation of biologically active ribonucleic acid from sources enriched in ribonuclease. Biochemistry. 18:5294-5299.

31. Maniatis, T., E. F. Fritsch, and J. Sambrook. 1982. Molecular cloning. A Laboratory Manual. Cold Spring Harbor Laboratory, Cold Spring Harbor, NY. 1-545.

32. Miller, J. S., B. M. Paterson, R. P. Ricciardi, L. Cohen, and B. E. Roberts. 1983. Methods utilizing cell-free protein-synthesizing systems for the identification of recombinant DNA molecules. Methods Enzymol. 101:650-674.

33. Coezy, E., J. Bouhnik, E. Clauser, F. Pinet, M. Philippe, J. Menard, and P. Corvol. 1984. Effects of glucocorticoids and antiglucocorticoid on angiotensinogen production by hepatoma cells in culture. In Vitro (Rockville). 29:528-534.

34. Galen, F. X., C. Devaux, T. Guyenne, J. Menard, and P. Corvol. 1979. Multiple forms of human renin. Purification and characterization. J. Biol. Chem. 254:4848-4855.

35. Laemmli, U. K. 1970. Cleavage of structural proteins during the assembly of the head of bacteriophage T4. Nature (Lond.). 227: 680-685.

36. Kalyan, N. K., and O. P. Bahl. 1981. Effect of deglycosylation on the subunit interactions and receptor binding activity of human chorionic gonadotropin. Biochem. Biophys. Res. Commun. 102:12461253.

37. Kalyan, N. K., and O. P. Bahl. 1983. Role of carbohydrate in human chorionic gonadotropin. Effect of deglycosylation on the subunit interaction and on its in vitro and in vivo biological properties. $J$. Biol. Chem. 258:67-74.

38. Armitage, P. 1971. Statistical Methods in Medical Research. Blackwell Scientific Publications, London. 1-504.

39. Kirk, R. E. 1978. Introductory Statistics. Brooks/Cole Publishing Company, Monterey. 1-438.

40. Workman, R. J., M. M. McKown, and R. I. Gregerman. 1974. Renin: inhibition by proteins and peptides. Biochemistry. 13:30293035 .

41. Sharon, N., and H. Lis. 1982. Glycoproteins. In The Proteins, vol 5. H. Neurath, and R. L. Hill, editors. Academic Press, New York. $1-144$.

42. Kornfeld, R., and C. Ferris. 1975. Interaction of immunoglobulin glycopeptides with concanavalin A. J. Biol. Chem. 250:2614-2619.

43. Baenziger, J. U., and D. Fiete. 1979. Structural determinants of concanavalin A specificity for oligosaccharides. J. Biol. Chem. 254: 2400-2407.

44. Muramatsu, T., N. Koide, C. Ceccarini, and P. H. Atkinson. 1976. Characterization of mannose-labeled glycopeptides from human diploid cells and their growth-dependent alterations. J. Biol. Chem. 251:4673-4679.

45. Hakimi J., and P. H. Atkinson. 1980. Growth-dependent alterations in oligomannosyl glycopeptides expressed in Sindbis virus glycoproteins. Biochemistry. 19:5619-5624.

46. Thomas, D. B., and R. J. Winzler. 1969. Structural studies on human erythrocyte glycoproteins. Alkali-labile oligosaccharides. J. Biol. Chem. 244:5943-5946.

47. Spiro, R. G., and V. D. Bhoyroo. 1974. Structure of the $O$ glycosidically linked carbohydrate units of fetuin. J. Biol. Chem. 249: 5704-5717.

48. Kessler, M. J., T. Mise, R.D. Ghai, and O. P. Bahl. 1979. Structure and location of the $O$-glycosidic carbohydrate units of human chorionic gonadotropin. J. Biol. Chem. 254:7909-7914.

49. Nasjletti, A., and G. M. C. Masson. 1972. Studies on angiotensinogen formation in a liver perfusion system. Circ. Res. 30 and 31(Suppl. 2):II-187-II-202.

50. Krakoff, L. R., and A. J. Eisenfeld. 1977. Hormonal control of plasma renin substrate. Circ. Res. 41(Suppl. 2):II-43-II-46.

51. Aden, D. P., A. Fogel, S. Plotkin, I. Damjanov, and B. B. Knowles. 1979. Controlled synthesis of $\mathrm{HBsAg}$ in a differentiated human liver carcinoma-derived cell line. Nature (Lond.). 282:615-616. 